\title{
Archaeology in the South Texas Sand Sheet: A Study of Chevron Properties in Brooks County
}

\author{
A. Joachim McGraw
}

Follow this and additional works at: https://scholarworks.sfasu.edu/ita

Part of the American Material Culture Commons, Archaeological Anthropology Commons, Environmental Studies Commons, Other American Studies Commons, Other Arts and Humanities Commons, Other History of Art, Architecture, and Archaeology Commons, and the United States History Commons

Tell us how this article helped you.

This Article is brought to you for free and open access by the Center for Regional Heritage Research at SFA ScholarWorks. It has been accepted for inclusion in Index of Texas Archaeology: Open Access Gray Literature from the Lone Star State by an authorized editor of SFA ScholarWorks. For more information, please contact cdsscholarworks@sfasu.edu. 


\section{Archaeology in the South Texas Sand Sheet: A Study of Chevron Properties in Brooks County}

\section{Creative Commons License}

\section{(c) (1) (8)}

This work is licensed under a Creative Commons Attribution-NonCommercial 4.0 International License 


\section{ARCHAEOLOGY IN THE SOUTH TEXAS SAND SHEET:}

\section{A Study of Chevron Properties in Brooks County}

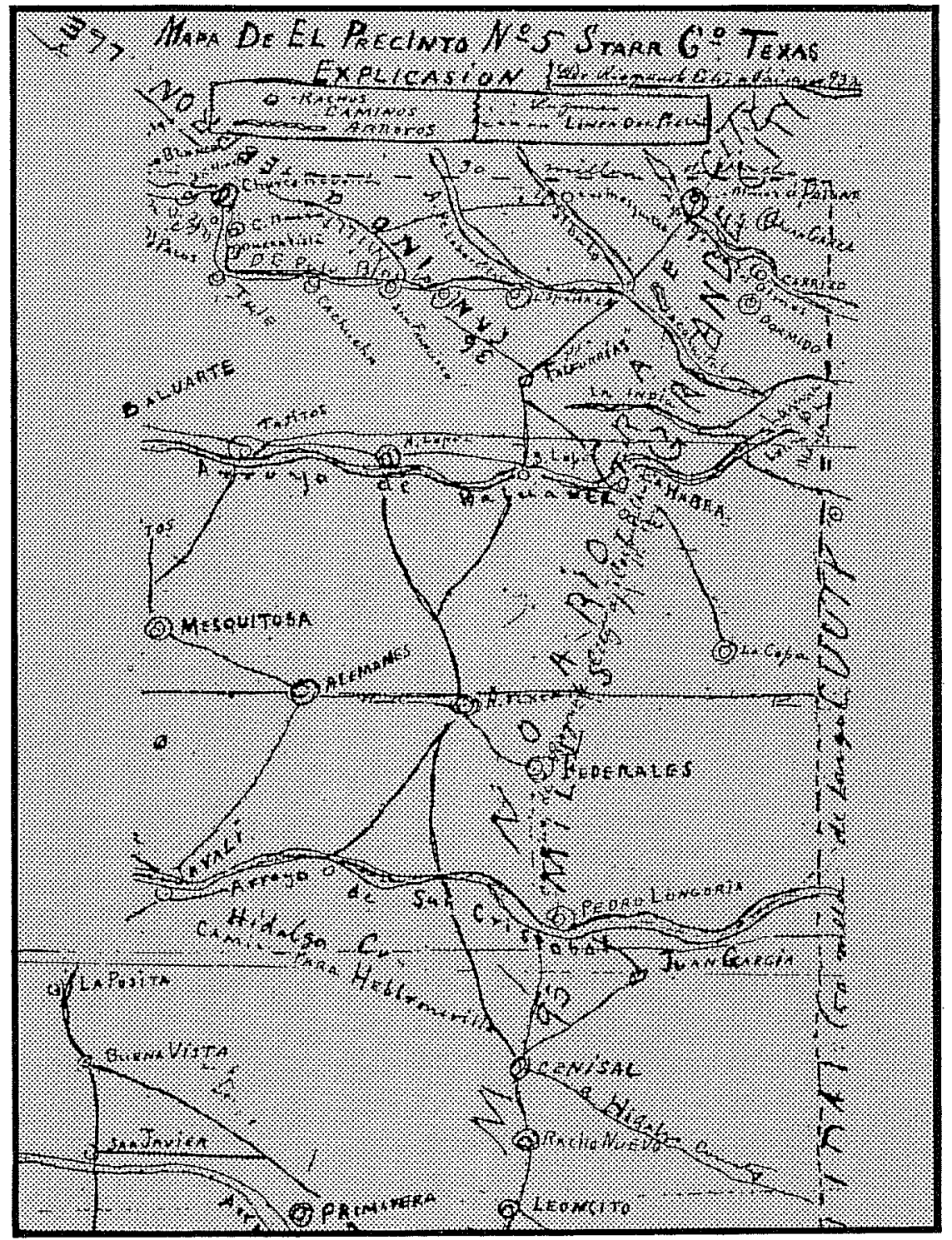

A. Joachim McGraw

With Contributions by Dennis A. Knepper, Margaret Greco, Ralph Snavely, and Stephen L. Black

CENTER FOR ARCHAEOLOGICAL RESEARCH THE UNIVERSITY OF TEXAS AT SAN ANTONIO ARCHAEOLOGICAL SURVEY REPORT, NO. 129 


\section{ARCHAEOLOGY IN THE SOUTH TEXAS SAND SHEET:}

\section{A STUDY OF CHEVRON PROPERTIES IN BROOKS COUNTY}

\section{A. Joachim McGraw}

With Contributions by Dennis A. Knepper, Margaret Greco, Ralph Snavely, and Stephen L. Black 
A list of publications offered by the Center for Archaeological Research can be obtained by sending $\$ 1.00$ to the Center for Archaeological Research, The University of Texas at San Antonio, San Antonio, Texas 78285. 


\section{ABSTRACT}

In the summer of 1982, archaeologists from the Center for Archaeological Research, The University of Texas at San Antonio, conducted an intensive survey of 4000 acres leased to the Chevron Resources Company in southwestern Brooks County, Texas. Twenty-seven archaeological sites were identified. Four prehistoric sites and two historic sites are recommended for further work in order to determine their potential for nomination to the National Register of Historic Places. 


\section{TABLE OF CONTENTS}

ABSTRACT . . . . . . . . . . . . . . . . . . . . . . . $i$ LIST OF FIGURES ...................... . . .

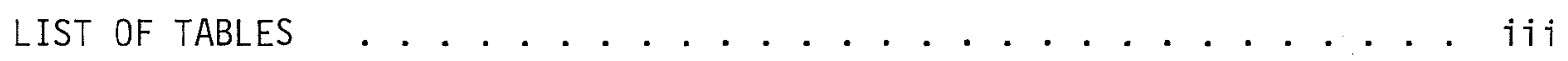
ACKNOWLEDGMENTS .............................. iv INTRODUCTION . . . . . . . . . . . . . . . . . . . . . . 1 ENVIRONMENTAL BACKGROUND . . . . . . . . . . . . . . . . . . . . 4 ARCHAEOLOGICAL AND HISTORICAL BACKGROUND . . . . . . . . . . 10 RESEARCH DESIGN .................................. 15 SITE DESCRIPTIONS ................................... 16

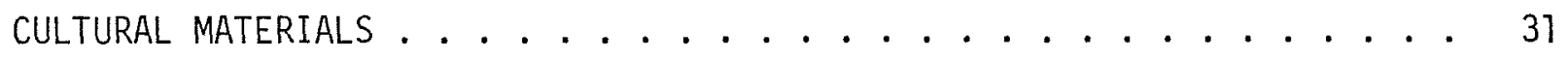
SUMMARY AND INTERPRETATIONS . . . . . . . . . . . . . . . 36

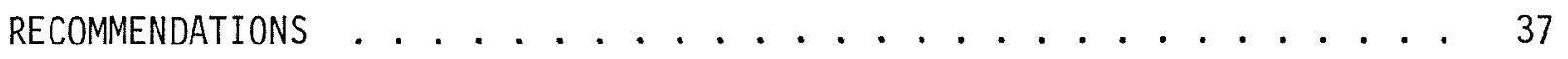
REFERENCES CITED ...................... . . 41 


\section{LIST OF FIGURES}

1. Regionar Map Showing Location of Study Area ... . . . . . . . . 2

2. Site Locations Within the Study Area of Brooks County, Texas . . . . . 3

3. Surface Geology of Brooks County . . . . . . . . . . . . . 6

4. Cross Section of Geologic Structures Within Survey Area . . . . . . 7

5. Mapa de el (sic) Precinto No. 5, Starr County, Texas ........ 13

6. Collected Artifacts from the Brooks County Survey . . . . . . . 35

7. Absolute Frequencies of Lithic Material Collections from Brooks and Duval Counties Archaeological Sites . . . . . . . . . . 38

\section{LIST OF TABLES}

1. Provenience of Collected Materials .............. 33

2. Attributes of Collected Bifaces and Unifaces . . . . . . . . 34

3. Summary of Recommendations, Brooks County Survey . . . . . . . . . . . 40 


\section{ACKNOWLEDGMENTS}

This archaeological survey report could not have been completed without the assistance and cooperation of a number of individuals. Many people from the Chevron Resources Company, especially Steve Borbas, were extremely helpful during the investigations. A. C. Jones, property owner, provided insights into local historical structures. Dr. Thomas R. Hester, Director, and Jack D. Eaton, Associate Director, of the Center for Archaeological Research provided their expertise and guidance. The field crew, Paul Lukowski, Ralph Snavely, and Stephen Black, often contended with adverse field conditions as well as unfriendly and venomous reptiles.

Mary Lou Ellis and Ann Young of the CAR staff provided extensive support. Most of the credit for the final report goes to Sharon Quirk, editor, for her patience and tenacity.

Carolyn Spock of the Texas Archeological Research Laboratory, Austin, was most cooperative during archival research.

Lastly, much of the background historical research was directly related to the contributions of Florence Schuetz, historian of Falfurrias, the cooperation of the Ed Rachal Memorial Library, and the Texas Ranger Museum, also of Falfurrias. 


\section{INTRODUCTION}

During June 1982, personnel from the Center for Archaeological Research, The University of Texas at San Antonio (CAR-UTSA), conducted a cultural resources survey of 4000 acres near Tacubaya, in southwestern Brooks County (see Fig. 1). The survey operations resulted in the identification and recording of 27 prehistoric and historic sites.

The purpose of the surface survey and a background literature research was to make an assessment of the prehistoric and historic potential of the Chevronleased properties before these locations would be extensively modified by proposed mining operations. The assessment of individual site significance and eventually, recommendations for further work, were based on site potential for nomination to the National Register of Historic Places as well as State Historic Landmarks. The cultural resources survey was carried out under the information requirements set forth in the National Historic Preservation Act of 1966, as amended, the Vernon Texas Civil Statute 4590f, as amended, and the regulations promulgated within, as well as the Guidelines for Archeological Investigations of Mining Areas in Texas (Texas Historical Commission 1981). The survey was conducted under the terms of an agreement (Service Order No. S113876) between Chevron Resources Company and the Center for Archaeological Research. Dr. Thomas R. Hester, Director of the CAR was Principal Investigator for the project. Jack Eaton, CAR Associate Director, was Co-Principal Investigator. The field work was conducted by Paul Lukowski, Ralph Snavely, Stephen Black, and Al McGraw of the CAR staff.

The survey area, identified on copies of USGS 1:24,000 scale topographic maps, was located on the properties of A. C. Jones and included portions of the Alta Mesa $0 i 1$ and Natural Gas Field in southwestern Brooks County, about two miles west of Tacubaya (see Fig. 2). A preliminary historical background search was also conducted at the Texas State Land Office, the Texas State Archives (Austin), and at the Brooks County Courthouse in Falfurrias, Texas. Additionally, the local Texana collection at the Ed Rachal Memorial Library, the Texas Ranger Museum, Florence Schuetz, and A. C. Jones (all of Falfurrias) were also consulted.

Field methodology during the survey work consisted of a series of parallel transects walked on specific compass azimuths to systematically cover as much of the area as possible. For convenience in the field, the study area was divided into quadrants determined by distinctive topographic features such as high upland areas, road and fence boundaries, etc. The quadrants were transected individually to insure more complete survey coverage and for better field control, especially in areas of dense brush that made map correlations difficult. Research methodology, including site recording and collection procedures, generally followed the guidelines presented in Hester, Heizer, and Graham's (1975) Field Methods in Archaeology and the Council of Texas Archeologists Performance Guidelines (CTA 1981:I-III), as well as the Guidelines for Archeological Investigations of Mining Areas in Texas (Texas Historical Commission 1981). Collection of materials was limited to diagnostic or otherwise significant artifacts. Data on newly discovered sites were recorded on standard site survey forms as used by the CAR, and all collected material, field records, and other survey data are on file at the CAR-UTSA. 


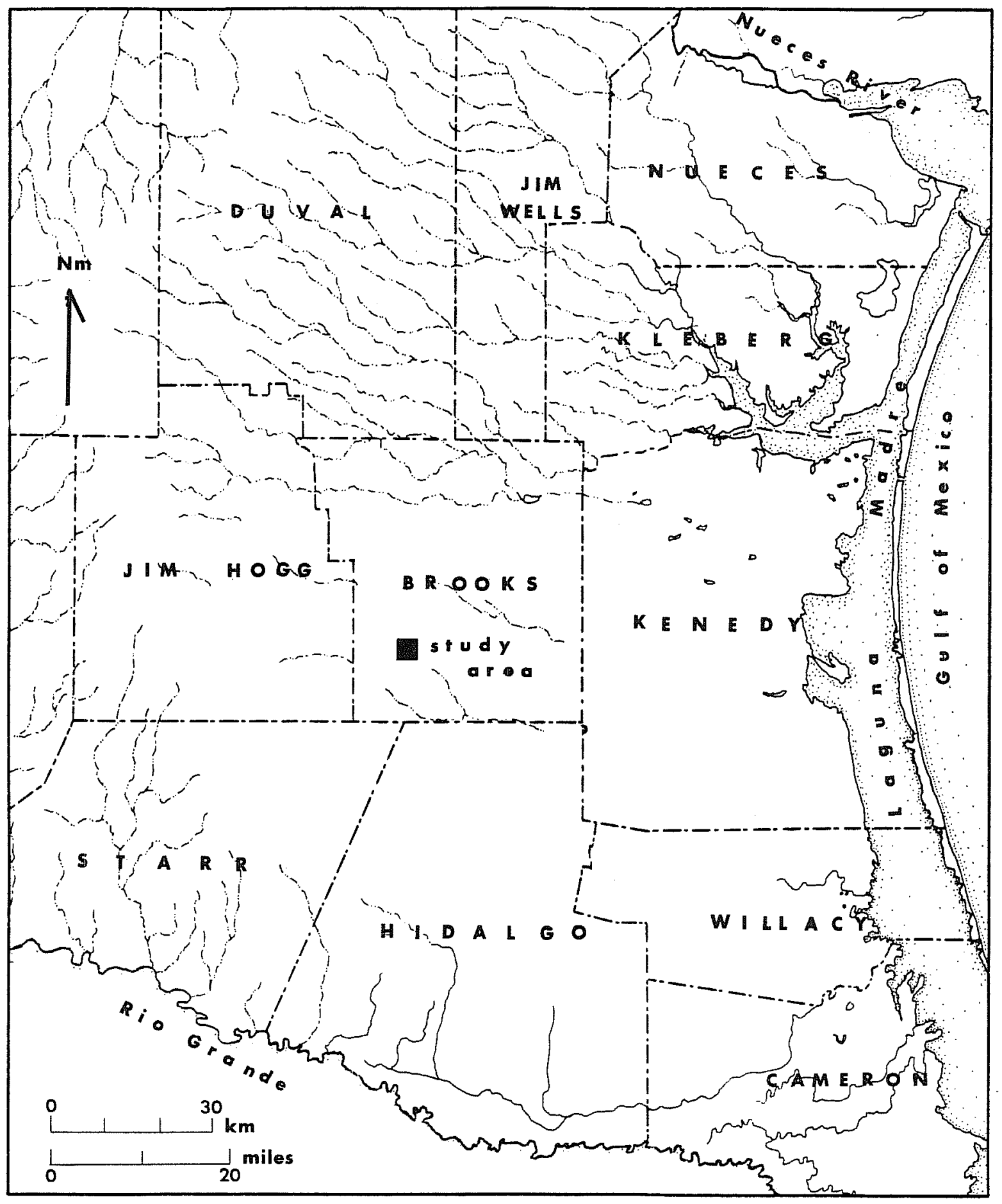

Figure 1. Regional Map Showing Location of Study Area. 
This page has been

redacted because it

contains restricted

information. 
Research methodology was directed not only toward the identification of individual sites but, also, if possible, toward a description of intersite relationships. This concept of not only identifying site locations but viewing them from a perspective of cultural and environmental interactions was considered to reflect more accurately the character and importance of individual sites.

The following pages will present a summary of the archaeology, history, and environmental data of the 27 newly identified sites. Associated recommendations for further work at specific sites are then presented. Recommendations for further work are based on criteria for potential eligibility for nomination to the National Register of Historic Places and the guidelines suggested in Guidelines for Archeological Investigations of Mining Areas in Texas (Texas Historical Commission 1981). Recommendations are presented in accordance with the National Historic Preservation Act of 1966, as amended, and Executive Order 11593.

\section{ENVIRONMENTAL BACKGROUND}

\section{Introduction}

Fundamental to any assessment of cultural resources is an understanding of local physical environments and available natural resources. Obviously, culture does not exist in a vacuum; man constantly interacts with his surroundings, functioning within an environmental context. It is necessary to examine this context, in a general way, in order to more fully determine the significance of any cultural resources observed. The following section is intended to provide a general introduction to the physical and biological environments of Brooks County, both present and past.

\section{Physiographic Environment}

The survey area lies in the southwest corner of Brooks County, a region of flat brush country along the edge of the South Texas Coastal Plain, midway between the Nueces River and the Rio Grande. This area is part of a larger geographic region known as South Texas, or the Rio Grande Plain, which covers approximately 22 million acres, bounded on the north by the Balcones Escarpment and the San Antonio River, on the east by the Gulf of Mexico, and in the south and west by the Rio Grande. This vast area was formed in the Tertiary period as receding seas left a series of slightly undulating plains, sloping gently to the southeast toward the modern coastline. Today the region is characterized by a savannah-prairie environment, with grasses and thorny brush predominant, and is primarily used for ranching (Lehmann 1969:4).

Much of the land in the Rio Grande Plain falls within the watershed of either the Rio Grande or Nueces River. The few streams found in Brooks County flow toward neither of these two rivers but for the most part, into saline lakes which have no outlets. In the northern portion of the county, Palo Blanco and Baluarte. Creeks flow only with storm runoff, draining into the Laguna Salada, or Salt Lake, located southeast of the county seat, Falfurrias (Meyers and 
Dale 1967:6). Salt Lake is approximately five kilometers in length and varies in width from $100 \mathrm{~m}$ to $800 \mathrm{~m}$. During the dry season, the lake may practically disappear, yet a small portion, some $65 \mathrm{~m}$ across, is said to always hold water, and has gained local notoriety as a bottomless sink. In the 1930s for example, a sounding cable was lowered to a depth of over $100 \mathrm{~m}$ without reaching bottom (Dyer 1938:3). Los 01mos Creek also flows through the extreme northeast corner of Brooks County and eventually into Baffin Bay and the Laguna Madre. South of the survey area, another intermittent stream, Vargas Creek, drains into the sma11, seasonal Lake Tasajal on the Hidalgo County line. No streams drain the survey area itself, as normal rainfall is absorbed by the relatively flat, sandy soits (Meyers and Dale 1967:6).

Most of Brooks County $\left(1447 \mathrm{~km}^{2}\right)$ is covered by a light tan-colored aeolian, or windblown, sand. The fine-grained sands are comparatively recent (i.e., Holocene in age) deposits blown by prevailing winds from coastal dunes in nearby Kenedy County (Johnson 1931:135). These sand and loess deposits general1y constitute the southern boundaries of the south Texas aeolian system. This extensive sand-silt-loess sheet is characterized by large areas of depressed relief. Vegetation ranges from sparse grasses to dense locales of mesquite, live oak, and thorn brush (Mallouf, Baskin, and Killen 1977:6-7). The south Texas sand sheet is composed of relict (stabilized) dunes, and many such are longitudinal in nature and aligned with the prevailing southeasterly winds (Russe11 and Suhm 1980:29-31). The sand overlies an earlier, Pliocene formation referred to as the Goliad Sand, which consists of sand and sandstone mixed with layers of silt, clay, and caliche (Barnes 1976). In the northwest of the county, the Goliad Sand reaches a maximum thickness of $300 \mathrm{~m}$ and outcrops on the surface, where associated caliche deposits produce a characteristic white coloration. In the survey area, the Goliad Sand averages $160 \mathrm{~m}$ in depth and is covered by up to $20 \mathrm{~m}$ of windblown sand (Meyers and Dale 1967:13). To the northeast, wind erosion has scoured out the loose surface sand altogether, revealing the underlying Goliad Sand with its white, hard-packed caliche deposits (see Fig. 3). In many spots, further erosion has produced shallow, playalike depressions. Although they are now quite dry, these depressions have been known to hold water, even in the recent past (unpubiished notes on file, Ed Rachal Memorial Library, Falfurrias, Texas). While earlier Tertiary formations, Lagarto Clay, Oakville Sandstone, and eventually Catahoula Tuff, are found below the Goliad Sand (Fig. 4), the Goliad Sand is the major water-bearing formation throughout the county, yielding small to moderate amounts of slightiy saline water to a maximum depth of $360 \mathrm{~m}$ (ibid.). The petroleum-rich Tertiary geologic deposits of the Gulf Coastal Plain consist of wedge-shaped sand and shale formations aligned in belts that parallel the modern shoreline of the Gulf of Mexico. Wedge-sets are named after the principal subsurface reservoirs of hydrocarbons. With in the study area, these wedge-sets form the "Frio Trend," a hydrocarbon basin ca. 50 miles wide, which includes the first two rows of counties inland. Faults and anticlines are the most significant oil and natural gas traps of the Frio Trend, and the Vicksburg fault system is associated with the local study area (Russe11 and Suhm 1980:33-39). Chert-bearing formations do not occur in the immediate vicinity of the study area. The nearest accessible 1 ithic resource area is along Palo Blanco Creek, near the Laguna Salada, where a few small chert pebbles are found in association with deposits of gypsum (Soil Conservation Service [SCS], Falfurrias office, personal communication).

The climate of Brooks County is generally quite mild. Southern Texas as a whole lies within a broad ecotone separating regions of North America to the 
This page has been

redacted because it

contains restricted

information. 

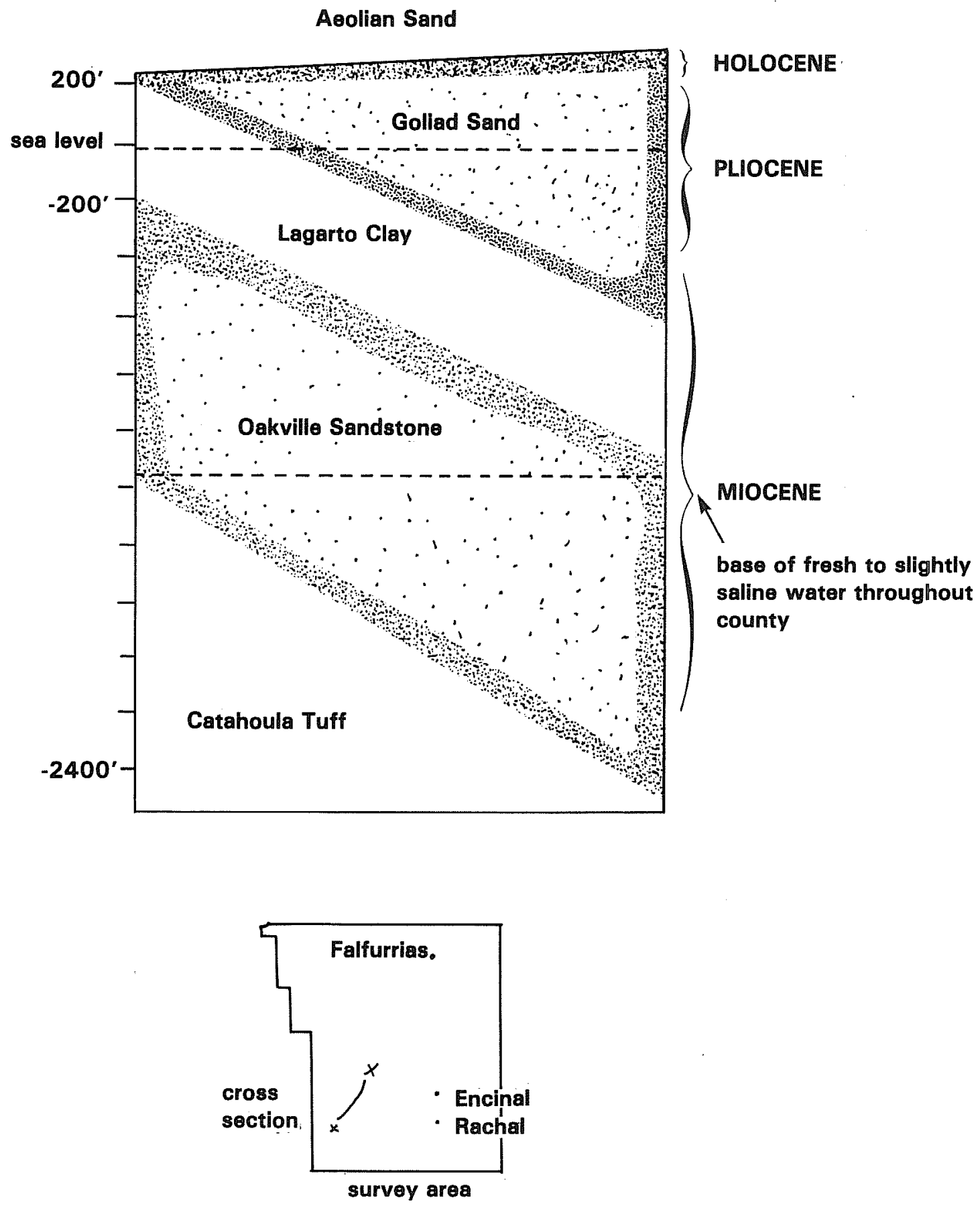

Figure 4. Cross Section of Geologic Structures Within Survey Area. Adapted from Meyers and Dale (1967:Fig. 17). 
east, characterized by sufficient moisture, from those to the west, with a pronounced moisture deficiency (BTair 1950:93). The portion of southern Texas in which Brooks County lies has a climate described as semiarid (Gunn et al. 1982:581). Since record keeping began in the early part of the 20th century, rainfa 11 has averaged 24.15 inches per year in Falfurrias (Thompson 1975:4). In the study area, the average is around 23 inches (Carr 1967:Fig. 2). Historically, records show there has been a wide variation in rainfall throughout southern Texas, both from month to month and from year to year. In Brooks County, less than nine inches of rain were recorded in 1917 (Thompson 1975:5), and in 1893, severe drought caused the permanent abandonment of many of the county's wells (Dyer 1938:13). In contrast, the occasional passage of hurricanes up the Gulf Coast brings heavy rains and flooding; almost 33 inches fe11 in September 1967 as a result of Hurricane Beulah (Thompson 1975:5). Normally, the wettest months are May, June, and September, when $36 \%$ of the annual rainfall is recorded. Offsetting rainfall is the annual evaporation rate, which is three times the average annual precipitation (Meyers and Dale 1967:7). Temperatures are moderate, averaging $73.3^{\circ} \mathrm{F}$ annually, and ranging from $57.8^{\circ} \mathrm{F}$ in January to $86.4^{\circ} \mathrm{F}$ in August (ibid.). Thus, while rainfall is deficient, the growing season is quite long, lasting about 300 days (Webb and Carrol1 1952:222).

\section{Biotic Resources}

Most of southern Texas, including Brooks County, is located within the Tamaulipan Biotic Province, as defined by Dice $(1943: 61)$ and revised by B1air (1950:102). Blair further described the climate as "megathermal," that is, exhibiting a marked deficiency of moisture for plant growth." Consequentiy, the major flora are xerophytic, or adapted to a limited water supply. Thorny brush species such as mesquite, certain types of Acacia, cenizo, and whitebrush are typica1. Although modern land clearing practiced since the 1930s has reduced the intensity of ground cover in much of western Brooks County (Davis and Spicer 1965:23), brush still chokes much of the region. In the survey area, huisache, mesquite, and cacti predominate, accompanied by Texas ebony. Wild grasses are varied and profuse, growing tall and dense enough to obscure the ground surface in many places (Johnson 1931:64-65). As a point of historical interest, the abundance of nourishing, "stirrup high" grasses in the vicinity was apparently a factor in prompting Richard King to establish the famous King Ranch to the northeast in the 1850s (Thompson 1975:1).

Present-day fauna include a mixture of nearctic species (typical of northern temperate zones) and neotropical species (typical of southern, subtropical zones in Central and South America). Blair (1950) lists a wide variety of animals in his Tamaulipan Biotic Province including numerous rodents, rabbit, deer, coyote, various snakes and lizards, tortoise, game birds such as dove, quail, and turkey, and a variety of migratory and raptorial birds. A summary of Blair's lists can be found in McGraw, Van Note, and Jones (1984).

Prehistoric Environment

In considering the environmental setting for cultural activity within the survey area, it should be noted that present conditions do not necessarily reflect the environmental conditions thousands or, in certain aspects, even 
of hundreds of years ago. Man has occupied southern Texas for at least 11,000 years (Hester 1980:28), and in that time, numerous and considerable changes in climate, flora, and fauna have taken place.

Palynology, the analys is of fossil pollens, is one of the most widely used methods of retrieving data concerning prehistoric environments. Unfortunately, due to the problems of long-term preservation, pollen analys is is not directly applicable to southern Texas. Nevertheless, inferences can be made from successful analyses in central Texas (e.g., Bryant 1977), southwest Texas (Shafer and Bryant 1977), and northeast Mexico (Bryant and Riskind 1980), and supported by other techniques including phytolith, or biosilicate, analysis (e.g., Robinson 1979, 1982; Gunn et al. 1982). What is known of the prehistoric environment of southern Texas is, then, necessarily general, providing a broad view of some of the major climatic and biotic changes which have occurred in the past.

About 14,000 years ago, at the close of the last full glacial period known as the Wisconsin, climate throughout the globe was cooler and wetter than at present, and most of Texas was a woodland area covered with deciduous forests. Southern Texas was probably less cool and wet than the central and eastern portions of the state, with a mixture of woodlands and savannah prevalent (Bryant and Riskind 1980:18). Late Pleistocene megafauna were present, and although none have been found in southern Texas in direct association with man, species including mammoth, mastodon, ground sloth, Bison antiquus, and glyptodon have been discovered along Palo Blanco Creek near the Brooks CountyKenedy County line in deposits dated around 9500 B.P., well after the known entrance of man into Texas (Suhm 1980).

By this time, some 9000 years ago, the Wisconsin ice shield was in full retreat far to the north, and Texas was experiencing a warming, drying, trend. With diminishing precipitation, the parkland-woodland environment slowly gave way to savannah, as grasses and shrubs became the predominant flora. Conditions were essentially like those of today by perhaps 3000 years ago (Bryant and Shafer 1977:18).

Yet, even then, the environment was different in several important respects from that known today. For example, it is likely there was more groundwater available than at present. Short-term climate changes and the recent lowering of the water table through intensive deep-well irrigation are factors cited in the drying up of many spring-fed creeks and streams in southern Texas (Hester 1980:34-35). Mesquite and other thorn brush were not as widely or densely distributed in the recent past (Gould 1975:4; Hester 1980:34).

Similarly, the faunal population has changed somewhat. Bison once ranged into central and southern Texas in a cyclical pattern from the southern High Plains (Dillehay 1974). Bison bone has been recovered from archaeological contexts as far south as McMullen County (Ha11, Black, and Graves 1982:473) and Jim Wells County (Hester 1977:29). Gray wolves, which followed bison as a major predator, would have also been present (Davis 1974:126). Pronghorn antelope have also ranged from the lower Rio Grande Valley to the Trans-Pecos area to the west (ibid.:248). In contrast to the species which are extinct or no longer known in the region, others, such as the armadillo and javelina, are relative newcomers, increasingly prolific in the 1800s (Hester 1980:37). 
Besides large game, prehistoric man in southern Texas had available a wide variety of food resources. Faunal lists from excavations in Jim Wells county show that, along with bison, a broad spectrum of small animal species were exploited (Hester 1977). But, for the most part, animal protein was never more than a seasonally important addition to a diet thought to consist mainly of plant foods. Prehistoric man sought plants which occurred naturally around him, and is known to have relied on plants that our own culture does not consider potential foods. A listing of available food resources would include plants such as mesquite, cactus, oak, and yucca, among others. Mesquite was put to a variety of uses, its wood as a raw material for tools and weapons, its sap and bark for medicinal, cosmetic, and decorative purposes (Felger 1977). In addition, ethnohistoric accounts detail the use of mesquite beans as a food resource by various southern Texas Indians (Newcomb 1961:42-43; Campbe11 and Campbe11 1981:39-40). Acorns from the Texas ebony and 1ive oak were also utilized by grinding into a flour for mush (Ha11, Black, and Graves 1982:472). Cacti provided yet another food source; Campbel1 and Campbel1 (1981:37-39) describe the gathering of prickly pear fruit by the Arbadao and Cuchendado Indians in the vicinity of what is now Jim Hogg County (directly west of the survey area) as witnessed by the Spanish explorer Cabeza de Vaca in 1535 . Yucca and sotol were also widely used. Ethnohistoric accounts indicate that pit roasting (Sjoberg 1953:84-85), as well as less formal processing methods ( $\mathrm{Hi11}$, Holdsworth, and Hester 1972), may have been used.

In summary, the environment of southern Texas has changed considerably during the period of man's presence there. Today, the land is harsh and dry, seemingly useful for little else than ranching. Without the benefits of modern technology--deep wells, refrigerated transport, and the like--the region would seem practically uninhabitable. And yet for prehistoric man it was not so forbidding. As a we11-known student of Texas Indian groups has observed, "for those who were wise to the possibilities of this land and catholic in their tastes, this was a livable and occasionally even a bountiful region" (Newcomb 1961:30).

\section{ARCHAEOLOGICAL AND HISTORICAL BACKGROUND}

\section{Regional Archaeological Background}

An overview of the archaeology of southern Texas has been covered in several recent publications. Mallouf, Baskin, and Killen (1977) provide an excellent review of the archaeology of "far southern Texas" that includes Brooks County as well as seven other southern counties. This summary has been updated by Day, Laurens-Day, and Prewitt (1981). Recent work in Duval County by McGraw, Van Note, and Jones (1984) provides a background discussion of the area immediately north of Brooks County. Volume 5 of the Choke Canyon Series (Hall, Black, and Graves 1982) includes a discussion of the archaeology of the entire southern Texas region. A final source for regional archaeological information is Hester (1980). Interested readers should consult the cited publications for details on the regional prehistory. 
Previous Archaeology in Brooks County

As of June 1982, seven archaeological sites had been officially recorded in Brooks County. The present report, adding 27 sites to this inventory, constitutes the most extensive archaeological investigation in the area. As an introduction to the newly recorded site data, the previous, officially recorded sites will be discussed.

In 1932, J. E. Pearce of the University of Texas at Austin learned of two prehistoric sites ( $41 \mathrm{BK} 1$ and 41 BK 2) near Falfurrias. Correspondence on file at the Texas Archeological Research Laboratory, Balcones Research Center, Austin, indicates that Pearce unsuccessfully attempted to obtain permission to excavate at a site located on the Don Sullivan Ranch, some eight miles southwest of Falfurrias. Little or no information other than brief locational data is available today.

It was not until 47 years later that any further professional work was conducted in Brooks County. Thomas C. Kelly of the Center for Archaeological Research (UTSA) recorded prehistoric sites in Brooks County during a helicopter-assisted survey of the proposed Tenneco pipeline route (Hester, ed. 1979). The sites were located on ridges overlooking the western arms of the Laguna Salada southeast of Falfurrias. Site 41 BK 3 covered a large area (approximately $600 \mathrm{~m}$ in length) and had extensive occupational materials including Late Prehistoric diagnostic artifacts. Site 41 BK 4 was a very small site less than $10 \mathrm{~m}$ in diameter containing an unidentifiable projectile point, a small end scraper, land snails, chert flakes, and marine shell. Given the dense nature of the vegetation, the site may well be much larger in size. Kelly noted that additional sites were probably present around Laguna Salada but concealed by dense vegetation.

In 1980, J. C. Tribble of Texas A\&M University surveyed a section of U.S. Highway 281 in Brooks County and recorded three sites. Two of the sites were comparatively recent (20th century) historic landmarks, the Trosada We11 (41 BK 5) and the "Halfway Tree" (41 BK 6). The third site Tribble recorded was a possible prehistoric locality marked by a single biface.

Recently, Carolyn Good and Jan Stokes of the U.S. Corps of Engineers (Galveston Branch) recorded five or six prehistoric sites along tributaries of the Laguna Salada as part of a planned flood control project. Good (personal communication, JuTy 6, 1982) is at present preparing a report on this work. She stated that a11 of the recorded sites were lithic scatters found in eroded conditions. Some bifacial and unifacial tools were collected, although artifact density per site was low. These sites will be officially reported to the Texas ArcheoTogical Research Laboratory, Austin, in the near future.

In addition to the above mentioned sites, correspondence between Florence Schuetz, chairperson of the Brooks County Historical Commission, and the State Archeologist in 1976 (then Curtis Tunnel1) called attention to several unrecorded archaeological sites in Brooks County. The Brooks County Texas Ranger Museum in Falfurrias also has a number of chipped stone tools on display including Late Prehistoric arrow points and Archaic dart points. Animal bones, from either prehistoric campsites or from noncultural Pleistocene deposits, have also been found at several unrecorded sites in the county (Florence Schuetz, personal communication). 
In summary, Brooks County is one of the least archaeologically studied counties in Texas. The area south and east of Falfurrias along intermittent water courses associated with the Laguna Salada contains numerous prehistoric sites dating at least to the Archaic time spans. Most sites appear to be located on topographic features (hills or ridges) overlooking water sources.

\section{Historical Summary: Regional and Brooks County ${ }^{1}$}

The earliest European description of the 1 and between the Nueces River and the Rio Grande was made by Cabeza de Vaca after his escape from his Indian captors in 1537. In describing this territory, he told of the abundance of deer, antelope, javelinas, and other animals which he referred to as "wild stock." Later maps designated this area as "Los Llanos de las Mesteñas" (The Plains of the Unbranded [or wild] Livestock). During the Texas revolutionary and Republic periods, wild horses became the most common of the wild. livestock.

By the early 18th century, Spain's political interest in areas north of the Rio Grande had been spurred by sporadic French intrusions. Spain's activities, often stymied by hostile natives, culminated in 1746 when the new Spanish state of Nuevo Santander was founded, which stretched from the Nueces River to the Rio Grande. The first Spanish land grants were located just below the Rio Grande, and those to the north of the river were granted in 1790. The earliest Spanish land grants located in present-day Brooks County were recorded in about 1880 to four wealthy cattle owners and/or influential Spaniards. No further grants were issued by Spain after 1810 because of increasing political unrest in Mexico which culminated in the Mexican Revolution. Eventually, while under the control of General Antonio Lopez de Santa Anna, the Mexican government issued its own land grants. Many of the Mexican land grants were converted to Texas grants in 1852 as the State of Texas validated legitimate prior claims. It was during these times that records show the study area was first occupied by Europeans. Archival research at the Texas State Land Office, Austin, shows that the 1835 land grant claims of Ysidro Garcia and Rafael Garcia Salinas were converted to Texas grants on February 23, 1852. The lands included five leagues of the Primavera and the Rancho Nuevo titles of the "Las Mesteñas" grant. Little is known of this area during this time, although Lino Trevino's map (see Fig. 5) shows that these ranches (and in addition, Rancho Leon Cito) were apparentiy still in operation during the period from 1873 to 1903.

From about 1836 to 1846, controversy ensued between Mexico and Texas as to whether the Nueces River or the Rio Grande constituted the border. In the interim, this area became a haven for both Anglo and Mexican bandits and smugglers.

By 1846, the border question had been settled and, as the political and economic conditions stabilized somewhat, ranching became the major agricultural business. In the Falfurrias area of northern, present-day Brooks County, not only cattle but sheep became important livestock. Ranches were small and relatively poor during this period. Prior to the Civil War, it was not uncommon to, at times, trade an acre of 7 and for a pound of sugar or coffee.

${ }^{1}$ Data extracted from Thompson (1975:9-30) and notes on file, Texana Collection, Ed Rachal Memorial Library, Falfurrias, Texas. 


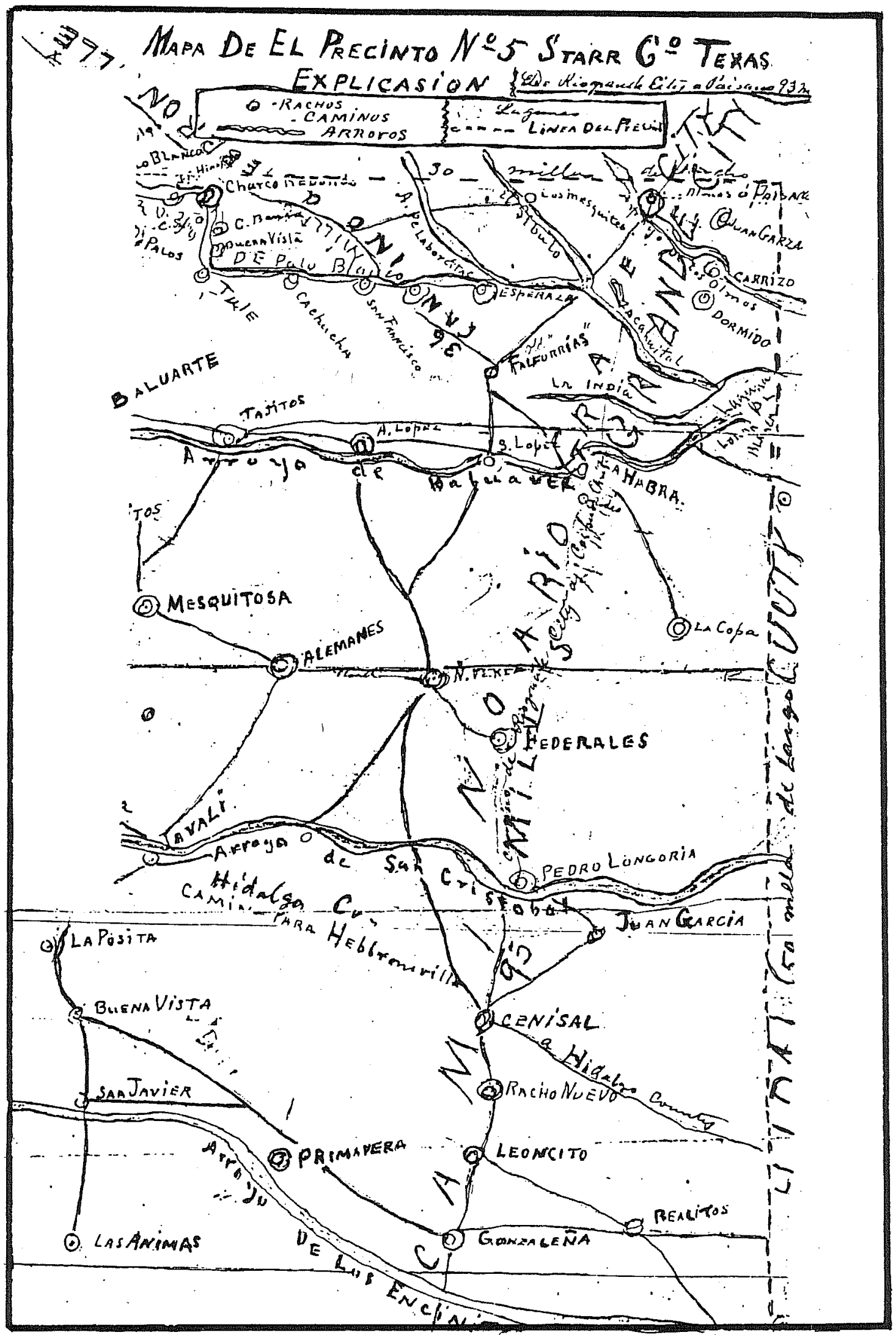

Figure 5. Mapa de el (sic) Precinto No. 5, Starr County, Texas. This map was drawn by Lino Trevino who served as a Justice of the Peace in Precinct 5, Starr County, Texas, and is dated 1873-1903. Map on file at the Texas Ranger Museum, Falfurrias, Texas. 
In post-Civil War southern Texas, Texans began to gather and drive wild cattle northward to markets where there was both a demand and a profit. The famous Chisholm Trail passed through Brooks County, and today there is a trail marker on U.S. Highway 281 in front of the Brooks County Courthouse.

By 1875 , banditry had become so rampant in the area that a group of Texas Rangers led by Captain Leander H. McNelly, a former Confederate guerilla, was formed to suppress the border violence. McNelly's exploits included operating under la ley de fuga (meaning that prisoners were killed on the spot if rescue was attempted) and his insistence on arming his Rangers with dated, but powerful single-shot Sharps buffalo rifles. McNelly, whose explanation was, "I don't want men who miss," preferred the .50 caliber Sharps to the more modern repeating Henrys and Winchesters because of the single-shot's extreme range and massive power. McNelly's efforts, which culminated in an unauthorized excursion into Mexico, brought an end to the large amount of cattle rustling and organized banditry in southern Texas.

During the latter years of the 19th century, major social, economic, and political changes overtook southern Texas. The continuing problems of lawlessness, a severe drought which crippled the cattle and sheep markets, the end of the open range, the emergence of aggressive, large-scale agri-businessmen, and the coming of the railroads, all contributed to an eventual reorganization of the political structure and political divisions of southern Texas. By 1911, Brooks County was created from Hidalgo, Starr, and Zapata Counties, and by 1913, Brooks County and portions of Duval County were subdivided to form Jim Hogg County.

These factors, plus the discovery of substantial reserves of crude $0 i 1$ and natural gas deposits in the early 20 th century, slowly precipitated a sizable economic boom which has ushered historic southern Texas into the modern era.

W. W. Jones and the Development of the Study Area

As the economic and cultural climate of the county changed, the study area was bought in 1912 by William W. Jones, a prominent Corpus Christi entrepeneur and cattleman. As Davis and Grobe, eds. (n.d.) point out, the force of his influence has been felt throughout southern Texas as Jones eventually owned and developed thousands of acres in Jim Hogg, Brooks, Hidalgo, Starr, and Duval Counties.

Born in Goliad County in 1855, the son of Captain A. C. Jones ("the Father of Beeville"), William Jones attended schools in Virginia and New York. Always interested in cattle, he acquired his first 2000 acres in Starr County in 1890, paying $\$ .50$ an acre. Developing artesian wells throughout, his prosperity grew, and he was later known as the last of the cattle barons. In 1905, he and his family moved to Corpus Christi where his influence helped to approve legislative passage of a bill forming Jim Hogg County. As his businesses grew, Jones' interests diversified into banking, real estate, and politics. Before his death in 1942, he formed the Mesteña $0 i 1$ Company to develop the minerals that might be found on his lands (unpublished notes on file, family library). 


\section{RESEARCH DESIGN}

The purpose of the current archaeological and historical research was to accomplish a cultural resources survey within the survey boundaries as identified by the Chevron Resources Company. The investigation consisted of a comprehensive, on-foot examination of the study area for the purposes of identifying and describing, as completely as possible, cultural resources. In addition, local and regional archival data were carefully reviewed for potential contributions to the historical records base. As noted in the Introduction section, specific methodologies were utilized during field work for effective survey coverage.

Before the commencement of actual field work, project archaeologists carefully reviewed the available archaeological and historical information not only to gain familiarity with the survey area, but also to formulate a series of research strategies to guide subsequent work. Several significant considerations were noted, and these are discussed below:

(1) Because of the general environmental similarity of the study area to previously investigated Duval County (see McGraw, Van Note, and Jones 1984), it was thought there would be a general similarity in the types, frequency, and general characteristics of potential Brooks County archaeological sites to those recorded in nearby Duval County. It was postulated that archaeological sites in the current study area would reflect temporary occupations and/or multifunctional activities in specific topographic contexts.

(2) Because the artifact collection from the Chevron Resources Company properties in the Duval County survey appeared to represent specific functions of occupation sites, it was predicted potential site locations in the Brooks County survey might reflect similar attributes.

(3) Because the survey area lacks any known water resources, it was postulated that potential archaeological sites would be generally less frequent and reflect a less intense nature of activity than those of Duval County.

(4) It was also thought that the lack of known lithic resources in the current study area would be a negative factor in determining both the material quality and frequency of potential lithic tools and debitage in Brooks County archaeological sites. A high relative frequency of retouched and exhausted lithic tools were predicted in the material collection due to the overall scarcity of raw materials.

In summary the research design formulated as a guide to field operations suggested that the majority of potential sites within the study area would: (1) be temporary hunting and gathering campsites; (2) be located on higher elevations (overlooks); (3) reflect a high frequency of reutilization of (scarce) lithic materials; and (4) be characterized by a lithic collection having a high ratio of tool forms compared to projectile points. Additionally, overall site frequency would be less than those identified in Duval County.

Because of these site projections, certain survey elements were emphasized in addition to methodologies previously mentioned: 
(1) Special care was taken to collect as much lithic material as possible for the largest possible surface collection. The potential benefits of this systematic form of intensive collection was thought to outweigh any negative effects such a methodology might have on possible future sampling. Because of the infrequency of lithic materials generally, each collected piece of debitage was later carefully analyzed to present the most complete picture of what types and frequencies of materials occurred on an intersite basis. The results were later compared to the material collection of the Duval County survey.

(2) Potential site locations, especially in relation to overlook areas were plotted on small-scale topographic maps prior to field work. These areas represented high probability site locations, following similarities to the Duval County sites.

(3) During a preliminary review of topographic maps and aerial photographs, a series of playalike depressions was identified in the survey area. The actual significance of these "blow-outs" was not known, but care was taken to investigate these topographic features on an individual basis, as well as the surrounding, associated topography.

A comparison of projected results and actual results is presented in the Summary and Interpretations section.

\section{SITE DESCRIPTIONS}

Twenty-seven archaeological sites were recorded during survey operations; 25 sites are prehistoric, and two sites are historic. Each site was given a permanent site number which is on file at the Texas Archeological Research Laboratory, Balcones Research Center, Austin, Texas. The trinomial identification system is a classification scheme in which the first two numbers (41) represent the state, the next two letters (BK) indicate the county, and the last two numbers identify the individual site. Consecutively numbered sites may, but do not necessarily, imply cultural relationships.

Site descriptions will include the following information:

Location: The site location is given as viewed from a general geographic, topographic, or geological perspective. Sites were plotted in relation to ranch roads, fencelines, etc. Figure 2 indicates the relative positions of the sites found. In compliance with Texas Historical Commission request, the exact locations with respect to 1 and features are not shown on the map. A map indicating the precise location of each site is on file at the CAR-UTSA.

Site Description: The physical characteristics of a site as well as identified cultural materials will be briefly discussed. A11 measurements will be given in meters $(\mathrm{m})$ unless otherwise noted.

Type of Site: The sites are typed as occupational (campsite), quarry, lithic workshop, or temporary occupation. Sites may often be described as multifunctional, if a variety of specific activities is thought to have taken place. 
Elevation: Approximate elevations of the site area are given in feet above mean sea leve1 (ms1). Elevations are plotted from USGS 7.5' topographic maps.

Topography and Soils: Brief descriptions of the soils and types of vegetation noted at individual sites will be discussed.

Site Condition: The condition of a site will focus on alterations to cultural deposits in relation to natural changes such as erosion or modern changes such as land clearing and cultivation.

Recommendations: An assessment of site significance based on the types of cultural materials noted, their frequencies, site features and condition, and other criteria related to National Register eligibility will be given. Recommendations may consist of no further work or limited subsurface testing to more clearly identify the extent and significance of individual sites. Limited testing may include hand-excavated or mechanically excavated $1-\mathrm{m}^{2}$ units or trenches, respectively, site mapping, special collections sampling, and systematic random sampling techniques.

\section{BK 8}

Location: Site 41 BK 8 is located at the intersection of the main service roads and just south of the mining camp area (see Fig. 2).

Site Description: Chert flakes, Rabdotus snail shells, and burned caliche rock are exposed in road cuts along this prehistoric site. Burned rock is lightly scattered throughout the site area. A small amount of lithic debitage as well as a small triangular biface was collected. The site has been damaged by road construction and is approximately $80 \times 25 \mathrm{~m}$.

Type of Site: Light occupation; possibly multifuctional.

Elevation: Approximately 300 feet above ms 1.

Topography and Soils: The site lies on the southern slopes of a hill between 295 and 300 feet above msl. Associated soils consist of a gray brown sandy, unconsolidated material. Vegetation includes tall grasses, huisache, mesquite, and some prickly pear.

Site Condition: Extensively damaged by road construction.

Recommendations: No further work is recommended; the site has been extensively damaged by the construction and regrading of two roads.

\section{BK 9}

Location: Site 41 BK 9 is located on the crest and slopes of a hill south of the Alta Mesa Camp and is bisected by a dirt ranch road running north to south (see Fig. 2). 
Site Description: This site is ca. $80 \times 30 \mathrm{~m}$ in size. A burned rock cluster, partially damaged by vehicle traffic, was noted exposed in a ranch road which transects the site. The small, disturbed feature was ca. $75 \mathrm{~cm}$ in diameter, and no cultural materials were associated with it. Examination of a nearby road cut revealed a thin band (ca. $10 \mathrm{~cm}$ thick) of compacted soil 45-50 cm below the surface. Several Rabdotus snail shells were observed in this layer, and it may be associated with a former ground surface as well as the lightly scattered cultural deposits. A small amount of lithic debitage was collected from the surface, but none was noted either associated with the disturbed burned rock cluster or within the compacted soil layer of the road cut.

Type of Site: Temporary occupation.

Elevation: 295 feet above ms 7 .

Topography and Soils: This site is located on the top and southern slope of a small hill. The soil consists of a light tan sandy loam overlying a more compacted gray brown material. Vegetation includes huisache, mesquite, blackbrush, and tall grasses.

Site Condition: Extensively disturbed by road construction and maintenance.

Recommendations: No further work is recommended due to the small site size, limited cultural deposits observed, and the extensive damage to the site area by vehicle traffic and road maintenance.

\section{BK 10}

Location: Site $41 \mathrm{BK} 10$ is situated in the vicinity of a pipeline access route within the northern section of the survey area and north of a road intersection northeast of a permanent hunter's camp.

Site Description: This site is ca. $30 \mathrm{~m}$ in diameter. Very few chipped stone materials were observed and collected. A light scatter of small burned rock fragments (some less than five centimeters in diameter) were noted.

Type of Site: Temporary occupation.

Elevation: 365 feet above msl.

Topography and Soils: The site is located on the northern slopes of a hill ca. $60 \mathrm{~m}$ southeast of a playalike depression. The vegetation consists of mesquite, persimmon, huisache, and at least five types of wild grasses. The soils are a light brown uncompacted sand over a slightly darker gray brown compacted sand.

Site Condition: Cultural material from the site was observed eroding downslope along an old roadbed. Artifacts were infrequent and widely scattered.

Recommendations: Due to lack of material concentrations, the small site area, and the extent of natural erosion, no further work is recommended at this site. 
41 BK 11

Location: Site $41 \mathrm{BK} 11$ is located on a pipeline route/sendero ca. $300 \mathrm{~m}$ south of the northern boundary of the survey area (see Fig. 2 ).

Site Description: The site area consists of a scatter of burned rock associated with a few fragments of chert debitage and some Rabdotus snail shells. Two sma11 bifacially worked tool fragments less than two centimeters in size were collected along with debitage and a small lump of burned clay. Site size is ca. $30 \times 40 \mathrm{~cm}$.

Type of Site: A multifunctional occupation area.

Elevation: 375 feet above ms 1 .

Topography and Soi1s: The site is situated on the margins and crest of a hil1top. Approximately $160 \mathrm{~m}$ to the east 1 ies a smal1 natural depression which apparently is an intermittent water source. The soil is a reddish brown sandy loam. Vegetation includes mesquite, huisache, and several types of tall grasses.

Site Condition: The site has been transected by a sendero later used as a road. As a result, most of the site area is badly damaged except for a small $10 \times 15-\mathrm{m}$ section; very 7 ittle appears to have remained intact.

Recommendations: Due to the lack of features, infrequent cultural materials, and the highly disturbed condition of the site, no further work is recommended.

41 BK 12

Location: Site 41 BX 12 is located on the southern slopes and hilltop of a rise ca. three kilometers north of the main entrance road to the survey area.

Site Description: Site deposits appear to be primarily intact subsurface materials; surface materials were found only along a road which has been cut through the site. Sma17, burned caliche rocks are lightly scattered across the site area as well as Rabdotus snail shells. Lithic artifacts included a small triangular biface, chert flakes, and a small core. Several unidentified marine she11 fragments were also observed. Site area cannot be accurately described, since it is primarily subsurface and presumably extends beyond the current survey boundaries; the site is estimated to be a minimum of $150 \mathrm{~m}$ in di ameter.

Type of Site: Multifunctional, moderate occupation site.

Elevation: 295 feet above ms 1 .

Topography and Soils: The site is located on a relatively flat hillside which gently slopes to the south. The soil is a light brown sandy loam. A darker gray brown clayey material was observed along the road cut at a depth of 
ca. $40 \mathrm{~cm}$. The area around the site has been cleared of brush and most trees, resulting in a dense, tall grass cover.

Site Condition: A road transects a portion of this site exposing the largest concentration of prehistoric materials observed during the survey. This suggests that further significant cultural materials may still lie intact below the surface of most of the site area.

Recommendations: Further testing in the form of hand-excavated $1-\mathrm{m}^{2}$ or $2-\mathrm{m}^{2}$ units screened through 1/4-inch or 1/8-inch wire mesh as well as soil and matrix samples to better determine the extent and significance of this location are recommended.

\section{BK 13}

Location: Site 41 BK 13 is located on an east to west road ca. 100 m east of a large oil storage tank, $800 \mathrm{~m}$ north of the Alta Mesa Camp.

Site Description: The site is ca. $100 \times 30 \mathrm{~m}$ in size and consisted primarily of scattered, burned caliche and Rabdotus snail shells. Only a small amount of lithic debitage and a small preform manufactured from a light-colored, coarse-grained chert was collected.

Type of Site: Light occupation.

Topography and Soils: The site is situated on the southwestern slope of a hill, facing a major playalike depression. At present the depression does not hold water but does support a thick growth of brush and tall grasses. The site is located in a cleared pasture with thick grasses and huisache regrowth.

Site Condition: The site is badly eroded, and cultural materials are scattered with no concentrations of artifacts or features noted.

Recommendations: Due to the light deposit of nondiagnostic cultural materials and the disturbed site condition, no further work is recommended at this site.

\section{$\underline{41 \text { BK } 14}$}

Location: Site 41 BK 14 is ca. 480 m west of the Alta Mesa Camp. An 011 well is located in the center of the site.

Site Description: This site consists of a light scatter of lithic debitage and several small caliche rocks. The site is ca. $40 \mathrm{~m}$ in diameter, and no chronologically diagnostic materials or features were observed.

Type of Site: Temporary occupation and a lithic workshop (chipping station).

Elevation: 290 feet above ms 1. 
Topography and Soils: The site is situated on a hilltop and extends to the upper western, northern, and southern slopes. The site area has been cleared and is characterized by tall grasses and huisache. The soil is a gray brown sandy loam.

Site Condition: The site area has been disturbed by road construction and the construction of oil field equipment.

Recommendations: Road and oil well maintenance as well as natural erosion have extensively damaged this site, therefore, no further work is recommended.

\section{$\underline{41 \text { BK } 15}$}

Location: Site 41 BK 13 is located on the northern margins of the survey area ca. $1.7 \mathrm{~km}$ west of a permanent hunter's cabin along an east to west fenceline. The northern portion of the site area is beyond the boundaries of the survey area.

Site Description: The site surface is composed of a light scatter of lithic debitage and a small amount of burned caliche. The total site area is ca. $30 \mathrm{~m}$ in diameter.

Type of Site: Light occupation.

Elevation: 265 feet above ms 1 .

Topography and Soils: Topography across the site is generally flat with a low rise approximately $20 \mathrm{~m}$ in diameter on the northern edge. A portion of the site is exposed within a road cut; subsurface deposits ca. 30-40 cm below the surface are characterized by an occasional Rabdotus snail she 11 and 7 ithic debitage. Although the location was at one time a cleared pasture, it now contains a dense regrowth of huisache, low brush, tall grasses, and cacti. The soil associated with this site is a reddish brown sandy loam.

Site Condition: Cultural materials have been partially disturbed by road construction through the site. The site is overgrown with dense vegetation.

Recommendations: A portion of this site is outside the survey area, and the remainder has been damaged by modern road construction and/or maintenance. No further work is recommended at this site.

\section{$\underline{41 \text { BK } 16}$}

Location: Site 41 BK 16 is located on the west side of a hill ca. $800 \mathrm{~m}$ northwest of a windmi11. A north to south sendero is $60 \mathrm{~m}$ east of the site.

Site Description: The site consists of a scatter of Rabdotus snail shells, some burned caliche, and a light scatter of lithic debris. Rodent burrows across the site have exposed some cultural materials, but no features or diagnostic materials were observed. The site is ca. $70 \times 90 \mathrm{~m}$. 
Type of Site: Temporary occupation.

Elevation: 260 feet above ms 1 .

Topography and Soils: The site is located on a relatively flat hilltop with a slight slope to the west. The soil is a loosely packed gray brown sandy loam. The vegetation within the site area includes low thorn brush, mesquite, and huisache.

Site Condition: The site area appears little disturbed by land clearing or mining operations.

Recommendations: Because of the larger size of this prehistoric site within the study area and its apparent intact subsurface components, further testing in the form of controlled, hand-excavated $1-\mathrm{m}^{2}$ or $2-\mathrm{m}^{2}$ units, as well as shovel tests and controlled soil and matrix sampling, is recommended to determine the nature, extent, and significance of this site.

\section{BK 17}

Location: Site 41 BK 17 is located in the northern margins of the survey area, on the west slope of a sma11 hill in the southwest corner of this northern area (see Fig. 2).

Site Description: Rabdotus snail shells and burned caliche predominate the archaeological evidence at this location although neither of these occur in concentrations. A small bifacial tool fragment as well as several pieces of lithic debris were collected from this site. Oval in shape, the site area is ca. $65 \times 40 \mathrm{~m}$.

Type of Site: Temporary occupation.

Elevation: 290 feet above ms 1 .

Topography and Soils: The site is located on the west side of a hill above a playalike depression. The soil is a tightly compacted grayish brown sandy loam. Blackbrush, mesquite, and huisache predominate the vegetation across the site.

Site Condition: The site is partially eroded and also damaged by an old road that passes through the location.

Recommendations: No further work is recommended at this location due to modern as well as natural disturbances of the original site area.

\section{BK 18}

Location: Site 41 BK 18 is located in the northern margins of the survey area on an upland ridge overlooking playa depressions to the north and south (see Fig. 2). 
Site Description: Site area is ca. $20 \mathrm{~m}$ in diameter. Archaeological evidence includes burned caliche, Rabdotus snail shells, and a small battered quartzite cobble.

Type of Site: Temporary occupation.

Elevation: 275 feet above ms 1 .

Topography and Soils: The site is located on the crest of a ridgeline which overlooks playalike depressions to the north and south. The soil is a $\tan$, uncompacted sandy loam.

Site Condition: The area is overgrown with tall grasses and thorn brush; the site itself appears to be moderately undisturbed.

Recommendations: Because of the lack of cultural materials and small physical site dimensions, no further work is recommended at this location.

\section{BK 19}

Location: Site $41 \mathrm{BK} 19$ is located ca. $1.3 \mathrm{~km}$ north of the southern edge of a private landing strip in the study area.

Site Description: Approximately $20 \mathrm{~m}$ in diameter, the site is characterized by an infrequent scatter of lithic debitage and a small, partially eroded burned rock cluster, ca. $70 \mathrm{~cm}$ in diameter.

Type of Site: Temporary occupation.

Elevation: 265 feet above ms 1 .

Topography and Soils: The site is located on the northeast edge of a saddle between two higher points. Directly east of the site lies a large (300-400 m in diameter) playalike depression. Huisache, thorn brush, and tall grasses predominate in the site area.

Site Condition: The site is partially eroded and overgrown with thorn brush and grasses.

Recommendations: Because of the small site size, lack of significant cultural materials, and the extent of erosion, no further work is recommended at this site.

\section{BK 20}

Location: Site 41 BK 20 is located ca. $200 \mathrm{~m}$ north of the northern edge of a private landing strip within the survey area.

Site Description: This prehistoric site contains a small scatter of burned caliche rock and an occasional Rabdotus snail shell exposed on the surface. A single decorticate chip was collected from this location. Total site area is less than $15 \mathrm{~m}$ in diameter. 
Type of Site: Temporary occupation.

Elevation: 285 feet above ms 1 .

Topography and Soils: The site is located on the highest hilltop in the immediate area. The soil is a gray brown sandy loam, and the area is covered by dense grasses and huisache.

Site Condition: The site is slightly eroded and overgrown by dense brush.

Recommendations: Due to the limited site size and lack of significant cultural materials, no further work is recommended at this site.

\section{$\underline{41 B K} 21$}

Location: Site 41 BK 21 is situated on the northern slopes of a high hill ca. $300 \mathrm{~m}$ northwest of the Alta Mesa Mining Camp.

Site Description: A large portion of this site was exposed in an extensive road cut. Profiles of the exposed area indicated a light scatter of cultural materials to a depth of at least $50 \mathrm{~cm}$. Surface materials are thinly scattered across ca. $100 \mathrm{~m}$. It is possible that erosional effects and past land clearing has somewhat displaced upper cultural deposits. Artifacts recovered from this site include a small triangular dart point, a small unifacial tool, and several debitage fragments.

Type of Site: Temporary to moderate occupation.

Elevation: 295 feet above ms 1 .

Topography and Soils: This site is on a northeastern slope facing a large playalike depression. The soil is a compacted gray brown sandy loam. Vegetation associated with this location includes blackbrush, huisache, and tall grasses.

Site Condition: The site is partially eroded, although road cut profiles indicate a substantial portion of this site is still intact and undisturbed.

Recommendations: This site represents one of the larger occupation locations within the study area with confirmed subsurface deposits. Further work in the form of hand-excavated $1-\mathrm{m}^{2}$ and $2-\mathrm{m}^{2}$ units and soil and matrix samples are suggested to further determine the significance of the site area.

\section{BK 22}

Location: Approximately $350 \mathrm{~m}$ southeast of $41 \mathrm{BK} 21$, site $41 \mathrm{BK} 22$ is located on an adjacent hilltop and overlooks a playalike depression to the south.

Site Description: The site is characterized by a road that cuts through portions of the site. Artifacts are exposed on the road and in erosional cuts near the road. The site is quite small, ca. $10 \times 20 \mathrm{~m}$, and contains a scatter of burned caliche rocks, Rabdotus snail shells, and infrequent debitage. 
Type of Site: Temporary occupation.

Elevation: 300 feet above ms 1 .

Topography and Soils: The site is located on the northeast slopes of a hilltop. The soil is a tan sandy loam. Vegetation in the vicinity includes huisache, mesquite, dense thorn brush, and tall grasses.

Site Condition: The site is partially disturbed by road construction activities and erosion.

Recommendations: Because of the limited site area, lack of significant cultural materials, and eroded condition of the site, no further work is recommended at this site.

\section{BK 23}

Location: Site 41 BK 23 is located on a hilltop south of well \#257, ca. $800 \mathrm{~m}$ southeast of the Alta Mesa Camp.

Site Description: Approximately $50 \mathrm{~m}$ in diameter, the site is slightly irregular in shape. Thirty-one pieces of chipped stone including three bifaces were collected from this site. While not spectacular, this does constitute one of the larger lithic collections from any individual site within the study area.

Type of Site: Sma11, temporary occupation site.

Elevation: 280 feet above ms 1 .

Topography and Soils: This site is situated on the southern slopes of a hill. A light scatter of cultural materials and burned rock extends upslope (westward). A playalike depression is located eastward ca. $75 \mathrm{~m}$. Dense brush and tall grasses obscure much of the surface of the site, and dominant flora includes mesquite, huisache, and thorn brush. The soil is an uncompacted, fine-grained, sandy loam.

Site Condition: The site is relatively undisturbed except for natural erosional processes, and it is possible that a substantial portion of the subsurface deposits may be intact.

Recommendations: Because of the amount of lithic debitage and its relatively intact preservation, further testing in the form of $1-\mathrm{m}^{2}$ and $2-\mathrm{m}^{2}$ hand-excavated units and soil and matrix sampling is recommended at this site to determine the extent and significance of subsurface cultural deposits.

\section{BK 24}

Location: Site 41 BK 24 is located along the eastern boundary of the survey area, ca. $1.25 \mathrm{~km}$ south of the entrance to the study area. 
Site Description: This small site, less than $20 \mathrm{~m}$ in diameter, contains a smal1 number of 1 ithic debitage fragments as well as several small siliceous cobbles and/or pebbles suitable for the manufacture of small lithic tools. No burned rock or Rabdotus snail shells were observed in this vicinity.

Type of site: Chipping station.

Elevation: 270 feet above msl.

Topography and Soils: The site is located on the eastern slopes of a small playa depression. This depression is characterized by a small outcropping of gypsum. The soil in the area is an uncompacted, grayish brown sandy loam. Vegetation is dense with tall grasses, dense blackbrush, mesquite, and huisache.

Site Condition: The site is partially eroded and densely overgrown with thorn brush.

Recommendations: Because of the limited site area and lack of significant cultural materials, no further work is recommended at this location.

\section{BK 25}

Location: Site 41 BK 25 is located ca. $100 \mathrm{~m}$ northwest of 41 BK 24 along a slight playalike depression overlook.

Site Description: A road through the site area has exposed a light scatter of lithic debitage, Rabdotus snail shells, and some burned caliche. Somewhat linear in shape, site dimensions measure ca. $200 \times 50 \mathrm{~m}$.

Type of Site: Temporary occupation.

Elevation: 280 feet above ms l.

Topography and Soils: The site is located on the southern slopes of a gently rolling hill, and directly to the south is a playalike depression. The soil is a light gray sandy loam. Vegetation includes mesquite, thorn brush, and tal1 grasses.

Site Condition: The site is partially eroded and densely overgrown with thorn brush.

Recommendations: While the site covers a moderately extensive area, the lack of significant cultural materials and the disturbed site condition suggest no further work is necessary at this location.

\section{BK 26}

Location: Site 41 BK 26 is located on a hilltop along the eastern margins of the survey area and ca. $550 \mathrm{~m}$ south of the entrance road to the study area. 
Site Description: The site is linear in shape and measures ca. $200 \times 75 \mathrm{~m}$. No burned caliche rock or Rabdotus snail shells were observed at this location; a medial biface fragment and several pieces of lithic debitage were collected.

Type of Site: Temporary lithic workshop center.

Elevation: 285 feet above ms 1 .

Topography and Soils: The site location is relatively flat with a slight slope to the south. The soil at this site is an uncompacted reddish, sandy loam. Vegetation is dominated by mesquite, huisache, and dense grasses.

Site Condition: This site is moderately eroded and partially disturbed by a ranch road which bisects the site.

Recommendations: Because of the lack of significant cultural materials and partially disturbed condition of a large portion of the site, no further work is recommended at this location.

\section{BK 27}

Location: Site 41 BK 27 is located ca. 300 m south of the Alta Mesa Camp and along a ranch road running north to south through the survey area.

Site Description: Approximately $100 \times 50 \mathrm{~m}$, the site is composed of a thin scatter of burned caliche and Rabdotus snail shells. Cultural materials consist of several pieces of 1 ithic debitage. No features or material concentrations were observed either on the surface or within a shallow profile exposed by road grading activities.

Type of Site: Temporary occupation.

Elevation: 280 feet above msl.

Topography and Soils: The site is situated on a slight slope. Topography is generally flat, and the soil is a light gray brown sandy loam. Mesquite, huisache, and thorn brush predominate the floral assemblage.

Site Condition: Moderately disturbed by road grading and natural erosion.

Recommendations: Because of the lack of significant cultural materials and the extent of surface damage, no further work is recommended at this site.

\section{BK 28}

Location: Site 41 BK 28 is located adjacent to the Leon Cito windmill in the northwest portion of the study area. 
Site Description: This historic site consists of a large and deep, hand-dug well and trough. The well opening measures ca. two by three meters and is at least 10-15 m deep. Limestone and caliche block lined, the well is now surrounded by unusually dense vegetation. The associated trough measures ca. $4 \times 10 \mathrm{~m}$, and the remaining walls are ca. $1.3 \mathrm{~m}$ in height. The long axis of the well and trough is east to west. The dense vegetation precludes an accurate estimate on the possibility of additional walls or other features.

Type of Site: Historic.

Elevation: 265 feet above ms 1 .

Topography and Soils: The site is located in a relatively flat area and is adjacent to a modern stock tank and watering trough. The soil is a gray brown sandy loam and unusually dense and tall weeds and grasses surround the site.

Site Condition: The site has been moderately damaged by natural erosion.

Recommendations: Current archival research does not shed any light on the origins of this well, although Lino Trevino's map (Fig. 5) does indicate a Rancho at Leon Cito (the windmi 11 location). This ranch, like the we11, may be related to the wall (house) remains at nearby 41 BK 29. Further work is recommended at this site, and specific suggestions are presented in the Recommendations of 41 BK 29.

\section{BK 29}

Location: Site 41 BK 29 is located ca. 150 m northwest of the Leon Cito windmill and adjacent to a ranch road running north to south, in the northwestern portion of the survey area.

Site Description: This historic site consists of a badly eroded wall composed of large caliche and limestone blocks cemented together with an adobelike material. Little remains of the original foundation to this structure except the remains of the south wall oriented northwest to southeast. The wall is ca. six meters in length, ca. three meters in height, and ca. $60 \mathrm{~cm}$ thick. No outbuildings or other features were noted within the vicinity after several intensive survey transects. The walls' proximity to the well and trough structure of 41 BK 28 suggests these two historic sites are related.

Type of Site: Historic occupation.

Elevation: 265 feet above ms 1 .

Topography and Soils: The site is located in a once-cleared area although high grasses and a recent growth of mesquite obscures much of the terrain and ground surface. The soil is a tan sandy loam.

Site Condition: The site is extensively damaged by natural processes and possibly modern land clearing. 
Recommendations: Preliminary investigations suggest both the remains of the occupation structure at this location and the well complex at 41 BK 28 are related to the Rancho Leon Cito noted on Lino Trevino's early map of the study area (see Fig. 5). Because of the lack of available data on both of these sites, further archival research is recommended to determine the actual site significance. In addition, if these sites are to be adversely impacted, testing in the form of $1-\mathrm{m}^{2}$ and $2-\mathrm{m}^{2}$ excavation units as well as a series of systematic shovel tests are recommended to more clearly define the extent of the walls and foundations. Preliminary research suggests these two sites may be related to the early Mexican land grant occupations of the study area, ca. 1850s and possibly as early as 1835 .

\section{BK 30}

Location: Site $41 \mathrm{BK} 30$ is located ca. $480 \mathrm{~m}$ south of $41 \mathrm{BK} 31$ in the southcentral portion of the study area. A ranch road passes through a portion of the site area.

Site Description: The site consists of a scatter of lithic debitage, burned rock, and Rabdotus snail shells. The site area is ca. $75 \times 30 \mathrm{~m}$. No features or material concentrations were observed.

Type of Site: Temporary occupation.

Elevation: 275 feet above ms 1 .

Topography and Soils: The site is located on a slight rise southwest of a playalike depression. The soil is an uncompacted, gray sand. The western margins of the site are in a cleared pasture with a moderate regrowth of huisache and mesquite.

Site Conditions: The area has been cleared of vegetation, and the surface appears root plowed. A portion of the site has been further damaged by construction of a ranch road.

Recommendations: Because of road construction and land clearing damage, no further work is recommended at this site.

\section{BK 31}

Location: Site 41 BK 31 is located in the central portion of the study area and is situated on the southern slopes of a small hill overlooking a small playalike depression.

Site Description: This prehistoric site is composed of a thin $7 i$ thic scatter associated with burned limestone caliche and Rabdotus snail shells. Site dimensions are estimated to be $75 \times 25 \mathrm{~m}$. No concentrations of cultural materials or features were noted.

Type of Site: Temporary occupation. 
Elevation: 280 feet above ms 1 .

Topography and Soils: This site is situated on a slope with higher ground to the west and a playalike depression southward. The soil is an uncompacted sandy loam. Vegetation across the site consists of huisache, tall grasses, mesquite, and thorn brush.

Site Condition: The site is partially eroded; the western portion has been cleared, and the eastern portion of the site is overgrown with thorn brush.

Recommendations: Because of the limited site area and lack of significant cultural materials, no further work is recommended at this site.

\section{BK 32}

Location: Site 41 BK 32 is located in the east-central portion of the study area, ca. $1.2 \mathrm{~km}$ south of the A1ta Mesa Camp.

Site Description: About $100 \mathrm{~m}$ in diameter, this prehistoric site is characterized by a light scatter of lithic debitage, burned rock, and Rabdotus snail shel1s. No features or material concentrations were noted throughout the site area. A possible olmos biface and a small collection of lithic debitage were collected at this site.

Type of Site: Temporary occupation.

Elevation: 280 feet above $\mathrm{ms}$.

Topography and Soils: The site is located on the crest of a small rise. The soil is an uncompacted, fine-grained sandy loam. Mesquite, huisache, and dense, tall grasses dominate the floral collection.

Site Condition: The site is moderately eroded.

Recommendations: Because of the low frequency of diagnostic materials, small site size, and natural erosion, no further work is recommended at this site.

\section{BK 33}

Location: Located on a hill ca. 500 m northeast of the Alta Mesa Camp, the site is bisected by a ranch road running north to south.

Site Description: About $100 \mathrm{~m}$ in diameter, the site consists of a 1 ight scatter of lithic debitage, burned caliche, and Rabdotus snail shells. No features or material concentrations were noted.

Type of Site: Temporary occupation.

Elevation: 295 feet above ms 1 . 
Topography and Soils: This site is located on the crest and slope of the highest elevation in the study area. The soil is a sandy, grayish brown loam. Vegetation includes blackbrush, mesquite, huisache, and grasses.

Site Condition: Partially eroded, a portion of the site is damaged by road construction.

Recommendations: Because of the lack of significant diagnostic materials and site damage by road construction, no further work is recommended at this site.

\section{BK 34}

Location: Site 41 BK 34 is located about $800 \mathrm{~m}$ south of the Alta Mesa Camp in the east-central portion of the study area.

Site Description: The site is $\mathrm{ca} .60 \mathrm{~m}$ in diameter and consists of a thin scatter of lithic debitage, burned rock, and Rabdotus snail shells.

Type of Site: Temporary occupation.

Elevation: 285 feet above ms 1 .

Topography and Soils: This site is situated on the western slopes of a small hill. The soil is a light gray sandy loam. Vegetation includes dense stands of blackbrush, mesquite, huisache, and tal1 grasses.

Site Condition: The site is partially eroded and also damaged by road construction.

Recommendations: Because of the limited site area and the extensive natural and modern damage to this site, no further work is recommended at this location.

\section{CULTURAL MATERIALS}

This section will present a brief description of the prehistoric material and several historic artifacts recovered during survey work. Prehistoric materials are tabulated by individual site collection and classified by type and frequency of chipped or battered stone. The materials are identified as formal chipped stone tools (projectile points, bifaces, and unifaces) and lithic debitage (flakes, cores, chips, and chunks). The presence of battered stone and modified or utilized debitage was also noted.

This report will detail the material collection from the current study area but will not discuss specific processes of the general 1ithic reduction sequence, a study of typological methodologies, or present a background to the study of prehistoric lithic materials. For the reader interested in these aspects of stone tool technology, the references presented in McGraw, Van Note, and Jones (1984) are recommended, as well as their Appendix, which defines commonly used terms in that (and this) study. 
Prehistoric Materials

A single, small projectile point and two point fragments, three preformlike bifaces, seven small, crudely made bifaces (possibly used as gougelike tools), two unifacial tool fragments, and three miscellaneous biface fragments were collected from various sites. Approximately nine percent of the debitage (184 specimens) reflected evidence of edge wear damage associated with utilization. In addition, three sma11 fragments of marine shell and 11 historic stone, bottle, and window glass artifacts were recovered. Provenience of these materials is presented in Table 1, and a brief description of individual bifaces and unifaces, by site, is presented in Table 2. Selected artifacts are illustrated in Figure 6.

\section{Projectile Points}

Only three sma11, triangular dart points and/or fragments were collected during the survey (see Table 2 for attribute data). One small dart point was surface collected from 41 BK 21 (Fig. 6,1), and a proximal portion was recovered from 41 BK 8 (Fig. 6,g) and 41 BK 26. In addition, in the context of an isolated find, a small triangular biface, possibly a projectile point (Fig, 6,i), was recovered at IF-1 (see Fig. 2 for location) about 500 m northwest of 41 BK 31. No specific chronological age can be associated with this small collection. The dart points are assumed to be related to activities occurring at some unknown time during the Archaic period.

\section{Bifacial and Unifacial Artifacts}

As noted, three preformlike bifaces ( $F i g, 6, j$ ), seven small, generally crudely worked but steeply edge beveled bifacial tools (Fig. 6,a-d), and three miscellaneous biface fragments (Fig. 6,f) were collected (see Tables 1 and 2). Two unifacially chipped artifacts were also recovered. The seven small bifacial tools are characterized by semi-invasive, steep beveling on one or more edges; several are roughly triangular in outline, and two (from 47 BK 12 and 41 BK 23 [Fig. 6,h]) are similar to the previously defined Olmos tool type (Shafer and Hester 1971).

\section{Miscellaneous Debitage}

One hundred eighty-four fragments of chipped and battered stone were recovered. Decorticate chips and chunks comprised approximately $54 \%$ of this material. In contrast, chipped stone flakes comprised less than 13\% (see Table 1). Cores, as such, consisted of small cobbles and large pebbles often less than five centimeters in length. Utilized debitage was only noted in nine percent of the sample and was most common on flakes and decorticate chips. A large portion of the collection (in excess of $60 \%$ ) appeared as fire reddened or possibly heat treated. 
TABLE 1. PROVENIENCE OF COLLECTED MATERIALS

\begin{tabular}{|c|c|c|c|c|c|c|c|c|c|c|c|c|c|c|c|c|c|c|c|c|}
\hline \multirow[b]{2}{*}{$\begin{array}{l}\text { Site } \\
\text { Number }\end{array}$} & \multirow[b]{2}{*}{ 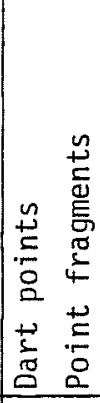 } & \multicolumn{3}{|c|}{ Bifaces } & \multicolumn{8}{|c|}{ Debitage } & \multirow[b]{2}{*}{ 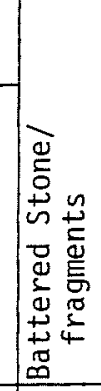 } & \multicolumn{4}{|c|}{$\begin{array}{l}\text { Utilized } \\
\text { Debitage }\end{array}$} & \multicolumn{2}{|c|}{$\begin{array}{l}\text { Misce 1- } \\
\text { laneous }\end{array}$} & \\
\hline & & & $\begin{array}{l} \\
0 \\
0 \\
0 \\
0 \\
0 \\
0 \\
0 \\
\\
\end{array}$ & & & $\begin{array}{ll} & \\
& \\
& \\
& \\
0 \\
0 \\
0 \\
0 \\
0 \\
0 \\
0\end{array}$ & & 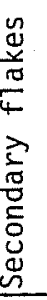 & 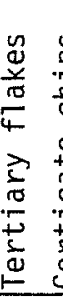 & 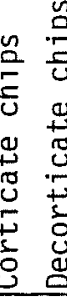 & & 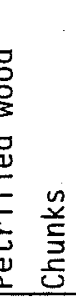 & & $\begin{array}{l}\mid \\
\frac{y}{\pi} \\
\frac{\pi}{4} \\
\end{array}$ & 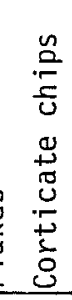 & 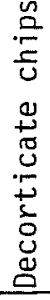 & 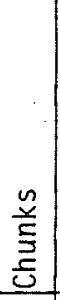 & 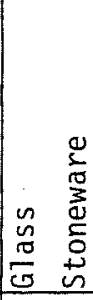 & 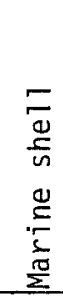 & 童 \\
\hline 41 BK 8 & 1 & & & & & 2 & & & & & & 2 & & & & & 1 & & & 6 \\
\hline 41 BK 9 & & & & & & 1 & 1 & & 1 & 6 & & & 1 & 1 & & & & 1 & & 12 \\
\hline 41 BK 10 & & & & & & & & 1 & & & & & & & 1 & 1 & & & & 3 \\
\hline 41 BK 11 & & 1 & 1 & & & & & & & & 4 & & & & & & & & & 7 \\
\hline $\begin{array}{llll}41 & \text { BK } & 12\end{array}$ & & 2 & & & & 5 & 2 & 1 & 11 & 211 & 1 & 22 & 1 & 2 & & & & & 3 & 62 \\
\hline 41 BK 13 & & & 1 & & & & & & & & & & & & & & 1 & & & 2 \\
\hline 41 BK 14 & & & & & & & & & & 1 & & & & & & & & & & 1 \\
\hline 41 BK 15 & & & & & & 2 & & & & & & & & & & & & & & 10 \\
\hline 41 BK 16 & & & & & & & & & & 1 & & & & & & 1 & & & & 2 \\
\hline $\begin{array}{llll}41 & \text { BK } & 17\end{array}$ & & & & & & 1 & & & & 1 & 7 & & & & & & & & & 3 \\
\hline 41 BK 18 & & & & & & & & & & & & & & & & & & & & 0 \\
\hline 41 BK 19 & & & & & & & & 1 & 1 & 2 & & & & & & & & & & 4 \\
\hline 41 BK 20 & & & & & & & & & & 1 & & & & & & & & & & 1 \\
\hline 41 BK 21 & 1 & & & & & & & & 1 & 1 & 1 & 1 & & & & & & & & 4 \\
\hline 41 BK 22 & & & & & & & & 2 & 1 & 2 & & & & & & & & & & 8 \\
\hline 41 BK 23 & & 2 & 1 & & & 7 & & & 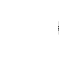 & 6 & & 11 & 1 & & & & & & & 29 \\
\hline 41 BK 24 & & & & & & 4 & & & 2 & 7 & & & & & & & & & & 15 \\
\hline 41 BK 25 & & & & & & 1 & & 1 & 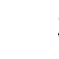 & 3 & & 7 & & 1 & & & & & & 17 \\
\hline 41 BK 26 & 1 & 1 & & & & & & 1 & & 1 & & & & 1 & & & & & & 6 \\
\hline 41 BK 27 & & & & & & 1 & & & & 2 & & & & & & & & 1 & & 4 \\
\hline 41 BK 28 & & & & & & & & & & & & & & & & & & & & 0 \\
\hline 41 BK 29 & & & & & & & & & & & & & & & & & & 27 & & 9 \\
\hline 41 BK 30 & & & & & 1 & 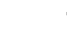 & 1 & & & 1 & & & & & & 1 & & & & 4 \\
\hline 41 BK 31 & & & & 1 & & & & & & & & & & & & & & & & 1 \\
\hline 41 BK 32 & & 1 & & 2 & & & & & 1 & 1 & & & & 1 & & 1 & & & & 7 \\
\hline 41 BK 33 & & & & & 1 & 3 & & 2 & 2 & 3 & & 3 & & 2 & & & 1 & & & 17 \\
\hline 41 BK 34 & & & & & & & & & & & & & & & & & & & & 0 \\
\hline Total & 12 & 7 & 3 & 3 & 22 & 27 & 4 & 9 & 03 & 48 & & 50 & 3 & 8 & 1 & 4 & 4 & 38 & 3 & 234 \\
\hline
\end{tabular}




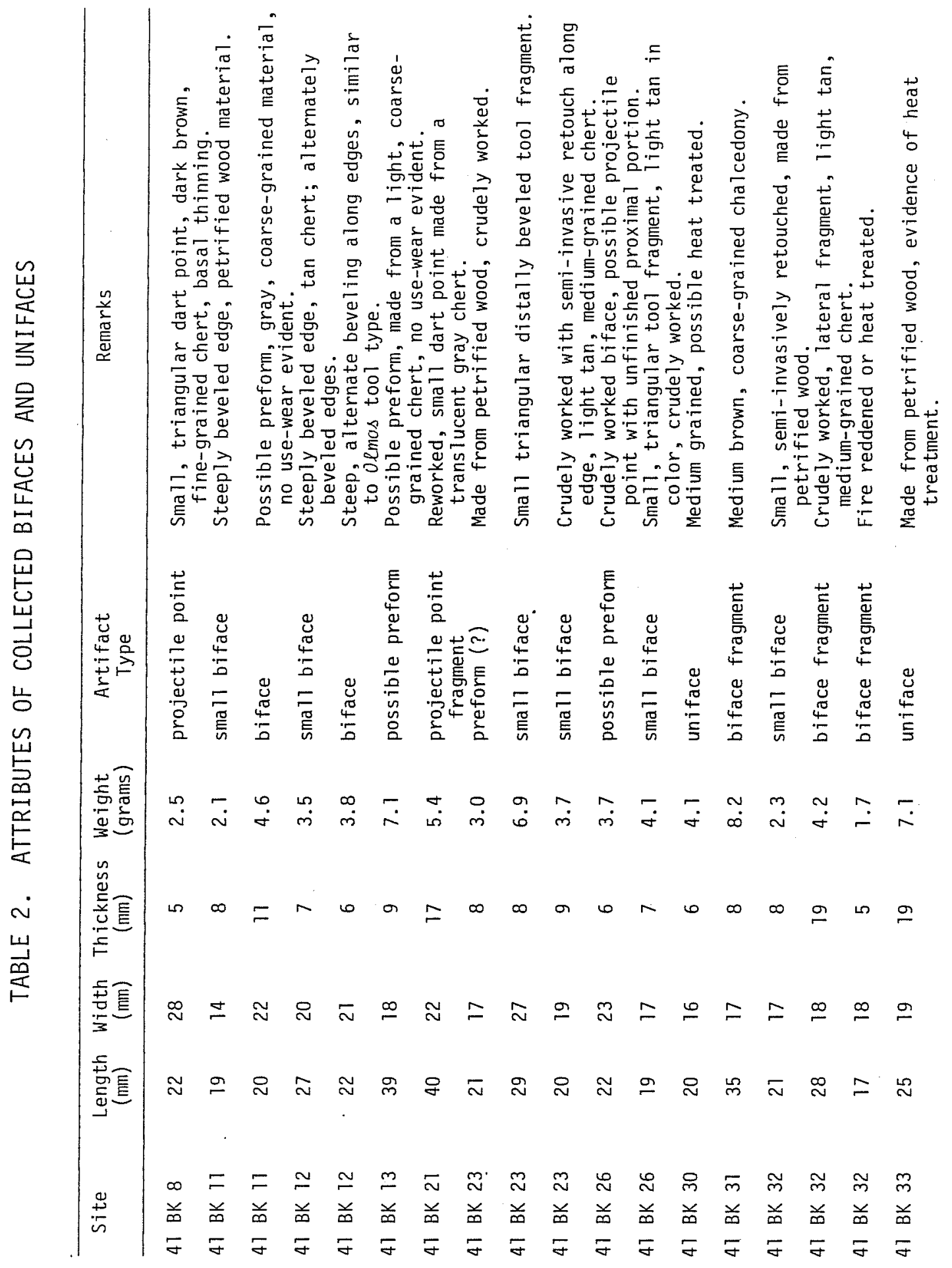




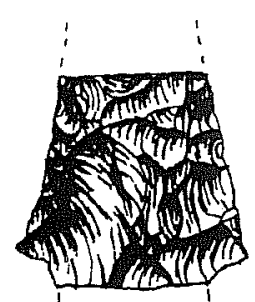

a
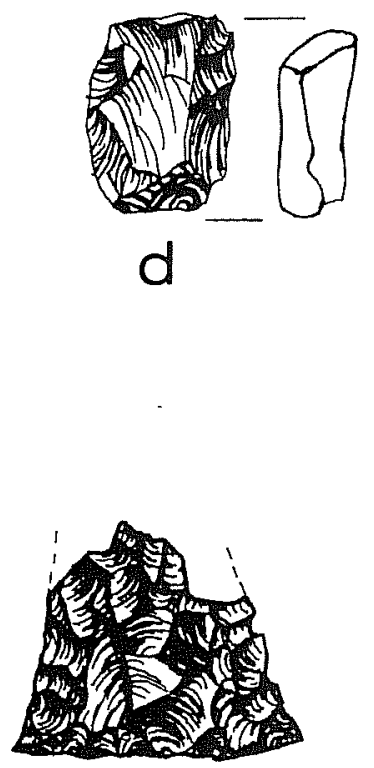

$\mathrm{g}$

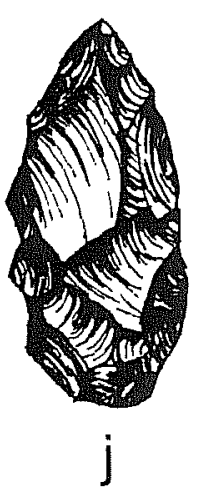

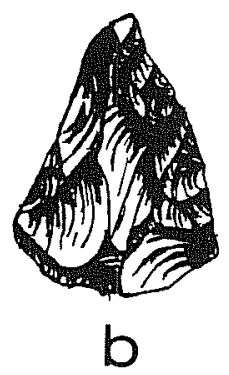
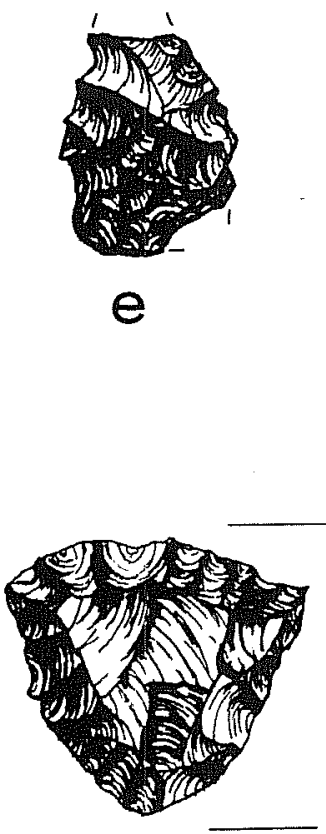

$\mathrm{h}$
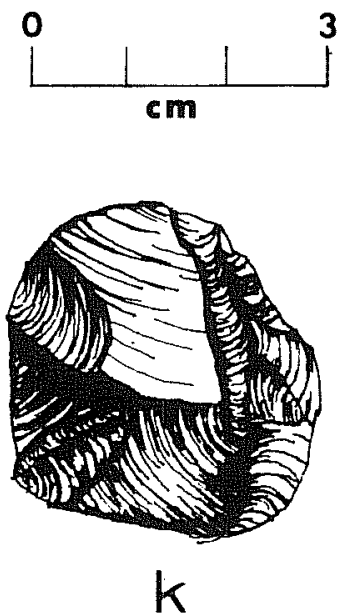
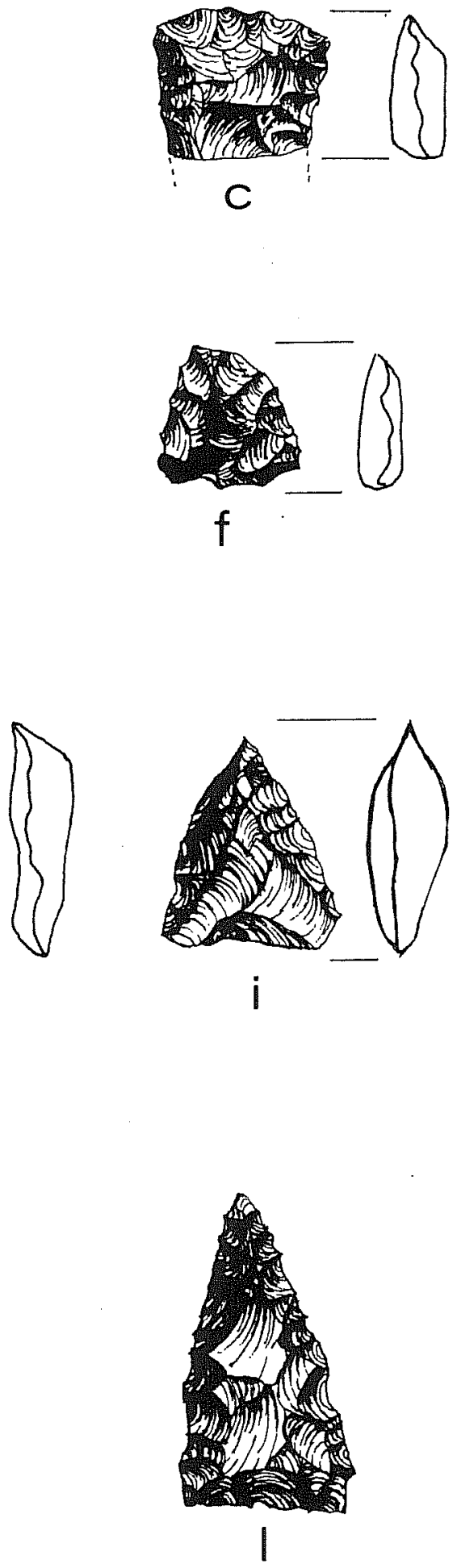

m. GRECO

Figure 6. Collected Artifacts from the Brooks Caunty Survey. a, medial fragment, thin biface, 41 BK 26; b, complete biface, 41 BK 12; c, small distal fragment of bifacial tool, 41 BK 32; d small bifacial tool, 41 BK 23; e, expended core, 41 BK 23; f, unidentifiable biface, 41 BK 32; g, proximal dart point fragment, 41 BK $8 ; h$, possible olmos tool, 41 BK $23 ; \dot{i}$ possible small projectile point, IF-1; j, crude biface, 41 BK 13; k, expended core, 41 BK 12; 1 , triangular dart point, 41 BK 21. 
Historic Materials

Only 11 smal1 pottery, bottle, and window glass fragments were recovered during survey operations (see Table 1 for provenience data). Seven sherds of undecorated stoneware were collected at the historic site of 41 BK 29 along with two chips of otherwise unidentifiable bottle and glass. Stoneware, as discussed in McGraw, Van Note, and Jones (1984), was commonly used in the late 19th to early 20 th centuries to store 1iquids. It was most popular until the 1900s and decreased in popularity shortly afterward.

\section{SUMMARY AND INTERPRETATIONS}

In summary, the 25 prehistoric sites are characterized as small, spatially discrete, activity areas often less than $100 \mathrm{~m}$ in diameter. Very little chipped stone debris was noted at any of these sites, and this may be directiy related to the lack of raw materials, siliceous stone pebbles, in or around the survey area. Less than 10 chips and flakes as well as an occasional stone tool fragment or projectile point commonly comprised the surface material distribution of individual sites. Almost all of the prehistoric sites evidenced some burned caliche, presumably once used as hearthstones or at least associated with burned rock clusters. All aboriginal sites were situated on (relatively) high overlook areas above small depressions that may have once served as intermittent waterholes. These sites, based on the limited amount of surface evidence available, are thought to represent the remains of small, temporary, multifunctional activity camps related to occupation and/or hunting overlook sites (Hester 1981).

The lithic collection is dominated by fire-reddened and/or heat-treated material; except for 18 small bifaces and unifaces, the remainder of the collection is composed of flakes, corticate and decorticate chips, chunks, and several pebble cores. A relatively small amount of this debitage has been utilized. A high percentage of this material was composed of brown to light brown, medium- to fine-grained chert, apparently originating from small pebble cores. Given the type of collection and the frequency of material types, as well as the physical site characteristics, a limited amount of lithic activity is postulated to have taken place at these prehistoric sites. Bifacial tools and fragments, rather than projectile points, occur most frequently in the collection, and preliminary interpretations suggest at least a slight emphasis on distinctive, steeply edgebeveled tool utilization.

In comparison with the lithic collection from the previous Chevron Resources Company properties in Duval County (McGraw, Van Note, and Jones 1984), several observations may be noted. First, while both the collections contain an unusually smal1 amount of materials (202 artifacts from Brooks County compared to a total of 160 artifacts from Duval County), the raw source materials differ substantially. Duval County materials were dominated by a milky-white cryptocrystalline material while those of the current study area originated in small-to medium-sized siliceous pebbles, medium to dark brown in color. A small amount of petrified wood material was also noted in the Brooks County collection. Given the fact that collected tool types from both areas represent 
(at least partially) the remains of portable tool kits, the actual source materials are thought to have originated near or around each individual survey area; i.e., no unusual intrusive materials were noted in either area, and the individual collections are dominated by a distinctive source material.

The actual frequency of bifaces (including projectile points), unifaces, and debitage from the current survey area and of previously surveyed portions of Duval County is illustrated in Figure 7 . While the total number of formal tools in both collections are sma11, differences are apparent in material types. Bifaces and unifaces comprise only nine percent of the collection from Brooks County but $16 \%$ from Duval County sites. Tertiary flakes constitute almost $30 \%$ of the collection from Duval County but less than eight percent from the sites in Brooks County. A major difference in the frequency of corticate chips and irregular chunks may be related to the differences in raw (resource) materials. A higher percentage of cortex material might be associated with the small pebble cores utilized in Brooks County rather than with the larger chunks of cryptocrystalline materials in Duval county. The percentage of modified and utilized debitage between the two areas is also striking; about nine percent for Brooks County sites compared to over 38\% for sites in Duval County.

Although the material collection totals may be generally similar in size, significant differences are thought to exist in the distribution of material types. While other explanations may exist, preliminary interpretations suggest substantial differences not in the intensity, but in the extent of prehistoric activities within these two areas. The differences of actual site locations within an environmental context (especially the proximity to intermittent, playalike water resources in Brooks County) also suggest qualitative differences (e.g., low density pattern of Hester 1981) between the prehistoric activities in these two locations.

\section{RECOMMENDATIONS}

Based on limited surface evidence, the newly identified sites are thought to represent the remains of small, temporary, multifunctional activity camps related to occupation and/or hunting overlook camps. These prehistoric activity locations are topographically similar and contain only a light scatter of cultural materials with few diagnostic materials and features. A major problem with the interpretation of the results of the field investigations has been the evidence of some buried deposits at many of the sites; most of the sites were found on erosional exposures, road cuts, or senderos. This buried site phenomenon is directly related to the high rate of aeolian sand deposits throughout the study area. This factor, in some ways, complicates any recommendations made in this report which are based primarily on surface observations. Stated simply, this report cannot offer comprehensive recommendations on sites which have only been surface surveyed but which apparently contain at least some buried deposits.

In the light of evaluating these sites within the National Register criteria, this report recommends that four of the larger prehistoric site locations, which evidenced distinct buried cultural deposits, be further tested by hand 


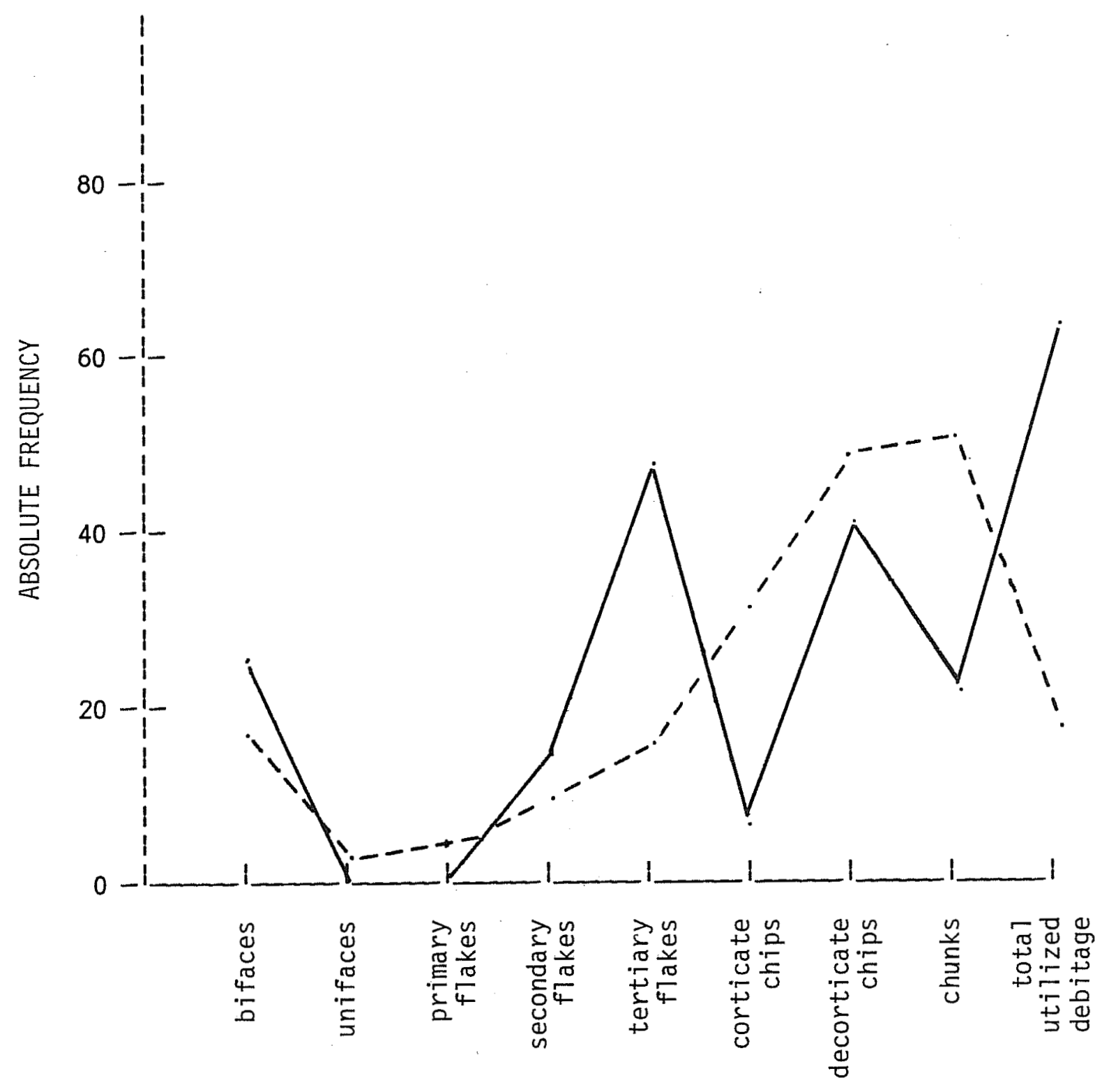

Debitage Frequencies, Duval County Lithic Materials

(McGraw, Van Note, and Jones 1984). Total $=160$.

Debitage Frequencies, Brooks County Survey. Total $=202$.

Figure 7. Absolute Frequencies of Lithic Material Collections from Brooks and Duval Counties Archaeological Sites. 
or mechanical excavations to determine the nature and the extent of buried cultural deposits. This testing would not only reflect the significance of cultural deposits at individual sites, but would also act as a sample from which to interpret the overall areal significance. This testing would take the form of a series of $50-\mathrm{cm}^{2}$ shovel tests and $1-\mathrm{m}^{2}$ or $2-\mathrm{m}^{2}$ excavation units screened through 1/4-inch or 1/8-inch wire cloth. Additionally, the use of a backhoe would be highly recommended in limited tests of the larger site area of 41 BK 12.

In addition to the four prehistoric sites, the historic sites of 41 BK 28 and 41 BK 29 (a massive hand-dug, stone-lined well and the remains of a 1 imestone and caliche structure, respectively) are also recommended for further work. Preliminary background research suggests that these two features are related to the Leon Cito Ranch, thought to exist in this area in the middle to late 19th century. A hand-drawn map identified from the files of the Texas Ranger Museum, Falfurrias (see Fig. 5) shows this site (Leon Cito) and a road leading to nearby "Racho [sic] Nuevo." This road, or a similar one, could still be identified on a 1954 aerial photograph on file at the local Soil Conservation Office in Falfurrias. The significance of the massive well structure at $41 \mathrm{BK} 28$ is not clear, although Mrs. Jimmie Picquet, Director of the John Conner Museum at Texas A\&I University at Kingsvi11e, suggested the description of this old well sounds similar to the well at Los ojellos, a National Register historic site near the border of Webb and Jim Hogg Counties. Further research may clarify the significance of the structures. Testing at $41 \mathrm{BK} 28$ and $41 \mathrm{BK} 29$ is recommended to consist of $50-\mathrm{cm}^{2}$ shovel tests, $1-\mathrm{m}^{2}$ and $2-\mathrm{m}^{2}$ excavation units, and plane table and/or alidade mapping of both sites as well as further background research.

Recommendations for all recorded sites are summarized in Table 3. 
TABLE 3. SUMMARY OF RECOMMENDATIONS, BROOKS COUNTY SURVEY

\begin{tabular}{|c|c|c|c|}
\hline Site Number & $\begin{array}{l}\text { No } \\
\text { Further } \\
\text { Work }\end{array}$ & $\begin{array}{l}\text { Limited } \\
\text { Testing }\end{array}$ & Comments \\
\hline $\begin{array}{lll}41 & \text { BK } & 8 \\
41 & \text { BK } & 9 \\
41 & \text { BK } & 10 \\
41 & \text { BK } & 11 \\
41 & \text { BK } & 12\end{array}$ & $\begin{array}{l}X \\
X \\
X \\
X\end{array}$ & $x$ & $\begin{array}{l}\text { small eroding hearth and } \\
\text { concentration of chipped } \\
\text { stone observed }\end{array}$ \\
\hline $\begin{array}{lll}41 & \text { BK } 13 \\
41 & \text { BK } 14 \\
41 & \text { BK } 15 \\
41 & \text { BK } 16\end{array}$ & $\begin{array}{l}x \\
x \\
x \\
x\end{array}$ & $x$ & $\begin{array}{l}\text { well-preserved deposits; } \\
\text { evidence of undisturbed } \\
\text { cultural materials }\end{array}$ \\
\hline $\begin{array}{ll}41 & \text { BK } 17 \\
41 & \text { BK } 18 \\
41 & \text { BK } 19 \\
41 & \text { BK } 20 \\
41 & \text { BK } 21\end{array}$ & $\begin{array}{l}x \\
X \\
X \\
X\end{array}$ & $x$ & $\begin{array}{l}\text { buried deposits noted in } \\
\text { erosional cuts; diagnostic } \\
\text { materials collected }\end{array}$ \\
\hline $\begin{array}{lll}41 & \text { BK } & 22 \\
41 & \text { BK } 23\end{array}$ & $x$ & $x$ & $\begin{array}{l}\text { several diagnostic materials } \\
\text { collected and evidence of } \\
\text { further buried deposits }\end{array}$ \\
\hline $\begin{array}{ll}41 & \text { BK } 24 \\
41 & \text { BK } 25 \\
41 & \text { BK } 26 \\
41 & \text { BK } 27 \\
41 & \text { BK } 28\end{array}$ & $\begin{array}{l}x \\
x \\
x \\
x\end{array}$ & $x$ & $\begin{array}{l}\text { historic, hand-dug we11 } \\
\text { structure }\end{array}$ \\
\hline $\begin{array}{lll}41 & \text { BK } & 29 \\
41 & \text { BK } & 30 \\
41 & \text { BK } & 31 \\
41 & \text { BK } & 32 \\
41 & \text { BK } & 33 \\
41 & \text { BK } & 34\end{array}$ & $\begin{array}{l}X \\
X \\
X \\
X \\
X\end{array}$ & $x$ & historic structure \\
\hline
\end{tabular}




\section{REFERENCES CITED}

Barnes, V. E., Project Director

1976 Geologic Atlas of Texas. McAllen-Brownsville Sheet. Bureau of Economic Geology, The University of Texas at Austin.

Blair, W. F.

1950 The Biotic Provinces of Texas. The Texas Journal of Science 2(1):93-117.

Bryant, V. M., Jr.

1977 A 16,000 Year Pollen Record of Vegetational Change in Central Texas. Palynology 1:143-156.

Bryant, V. M., Jr. and D. H. Riskind

1980 The Paleoenvironmental Record for Northeastern Mexico: A Review of the Pollen Evidence. In Papers on the Prehistory of Northeastern Mexico and Adjacent Texas, edited by J. F. Epstein, T. R. Hester, and C. Graves:7-33. Center for Archaeological Research, The University of Texas at San Antonio, Special Report 9.

Bryant, V. M., Jr. and H. J. Shafer

1977 The Late Quaternary Paleoenvironment of Texas: A Model for the Archeologist. Bulletin of the Texas Archeological Society 48:1-25.

Campbe11, T. N. and T. J. Campbe11

1981 Historic Indian Groups of the Choke Canyon Reservoir and Surrounding Area, South Texas. Center for Archaeological Research, The University of Texas at San Antonio, Choke Canyon Series 1.

Carr, J. T., Jr.

1967 The Climate and Physiography of Texas. Texas Water Development Board, Report 53.

Council of Texas Archeologists (CTA)

1981 Guidelines for Curation Standards and Procedures. Council of Texas Archeologists, Newsletter 5(2).

Davis, W. B.

1974 The Mammats of Texas. Texas Parks and Wildife Department, Bulletin 41 . 
Davis, E. A. and E. H. Grobe, eds.

n.d. The New Encyclopedia of Texas. Texas Development Bureau, Dallas.

Davis, R. B. and R. L. Spicer

1965 Status of the Practice of Brush Control in the Rio Grande

Plain. Texas Parks and Wildlife Department, Bulletin 46.

Day, D. W., J. Laurens-Day, and E. Prewitt

1981 Cultural Resources Surveys and Assessments in Portions of Hidalgo and Willacy Counties, Texas. Prewitt and Associates, Reports of Investigation 15. Austin, Texas.

Dice, L. R.

1943 The Biotic Provinces of North America. University of Michigan Press, Ann Arbor.

Dillehay, T. D.

1974 Late Quaternary Bison Population Changes on the Southern Plains. Plains Anthropologist 19(65):180-196.

Dyer, $L$.

1938 The History of Brooks County. M.A. thesis, College of Arts and Industries, Texas A\&I University, Kingsville.

Felger, R. S.

1977 Mesquite in Indian Cultures of Southwestern North America. In Mesquite: Its Biology in Two Desert Ecosystems, edited by B. B. Simpson:150-176. Dowden, Hutchinson, and Ross, Stroudsburg, Pennsyivania.

Gould, F.W.

1975 The Grasses of Texas. Texas A\&M University Press, College Station.

Gunn, J., T. R. Hester, R. Jones, R. L. Robinson, and R. A. Mahula

1982 Climatic Change in Southern Texas. In Archaeological Investigations at Choke Canyon Reservoir, South Texas: The Phase I Findings, by G. D. Hall, S. L. Black, and C. Graves:578-596. Center for Archaeological Research. The University of Texas at San Antonio, Choke Canyon Series 5. 
Hal1, G. D., S. L. Black, and C. Graves

1982 Archaeological. Investigations at Choke Canyon Reservoir, South Texas: The Phase I Findings. Center for Archaeological Research. The University of Texas at San Antonio, Choke Canyon Series 5.

Hester, T. R.

1977 Archaeological Research at the Hinojosa Site (41 JW 8), Jim We11s County, Texas. Center for Archaeological Research. The university of Texas at San Antonio, Archaeological Survey Repart 42.

1980 Digging Into South Texas Prehistory: A Guide for Amateur Archaeologists. Corona Publishing Company, San Antonio.

1981 Tradition and Diversity Among the Prehistoric Hunters and Gatherers of Southern Texas. Plains Anthropologist 26(92):119128.

Hester, T. R., ed.

1979 A Preliminary Archaeological and Historical Assessment of the Proposed Tenneco Pipeline: Hidalgo to Victoria Counties, Texas. Center for Archaeological Research, The University of Texas at San Antonio, Archaeological Survey Report 51.

Hester, T. R., R. F. Heizer, and J. A. Graham

1975 Field Methods in Archaeology. 6th edition. Mayfield Publishing Company, Palo Alto, California.

Hi11, T. C., Jr., J.B. Holdsworth, and T. R. Hester

1972 Yucca Exploitation: A Contemporary Account from the Rio Grande Plain. In Archaeology Papers Presented to J. W. House, edited by T. R. Hester. Berkeley.

Johnson, E. H.

1931 The Natural Regions of Texas. University of Texas Bulletin 3113 .

Lehmann, V.W.

1969 Forgotten Legions: Sheep in the Rio Grande Plain of Texas. Texas Western Press, University of Texas at El Paso. 
Mallouf, R. J., B. J. Baskin, and K. L. Killen

1977 A Predictive Assessment of Cultural Resources in Hidalgo and Willacy Counties, Texas. Texas Historical Commission, Office of the State Archeologist, Survey Report 23.

McGraw, A. J., B. J. Van Note, and C. J. Jones

1984 Archaeology of the Brasada: A Cultural Resources Assessment of the Chevron Resources Company Properties in Northeastern Duval County, Texas. Center for Archaeological Research, The University of Texas at San Antonio, Archaeological Survey Report 113 (in preparation).

Meyers, B. N. and 0. C. Dale

1967 Ground-Water Resources of Brooks County, Texas. Texas water Development Board, Report 61.

Newcomb, W. W., Jr.

1961 The Indians of Texas. University of Texas Press, Austin.

Robinson, R. L.

1979 Biosilica and Climatic Change at 41 GD 21 and 41 GD 21A. In Archaeological Investigations of Two Prehistoric Sites on the Coleto Creek Drainage, Goliad County, Texas, by D. E. Fox:102113. Center for Archaeological Research, The University of Texas at San Antonio, Archaeological Survey Report 69.

1982 Biosilica Analysis of Three Prehistoric Sites in the Choke Canyon Reservoir, Live Oak County, Texas: Preliminary Study of Climatic Implications. In Archaeological Investigations at the Choke Canyon Reservoir, South Texas: The Phase I Findings, by G D. Ha11, S. L. B1ack, and C. Graves:597-610. Center for Archaeological Research. The University of. Texas at San Antonio, Choke Canyon Series 5.

Russe11, J. L. and R. Suhm

1980 Geology of Clay Dunes, Baffin Bay, and the South Texas Sand Sheet. Paper presented at the 83rd Annual Meeting of the Texas Academy of Science, Corpus Christi, Texas.

Shafer, H. J. and V. M. Bryant, Jr.

1977 Archeological and Botanical Studies at Hinds Cave, Val Verde County, Texas. Texas A\&M Anthropology, Laboratory, Special Series 1. 
Shafer, H. J. and T. R. Hester

1971 A Study of the Function and Technology of Certain Bifacial Tools from Southern Texas. Texas Historical Commission, office of the State Archeologist, Report 20.

Sjoberg, A. F.

1953 Lipan Apache Culture in Historical Perspective. Southwestern Journal of Anthropology 9(1):76-98.

Suhm, R. W.

1980 The La Paloma Mammoth Site, Kenedy County, Texas. In Papers on the Archaeology of the Texas Coast, edited by L. Highley and T. R. Hester:79-103. Center for Archaeological Research, The University of Texas at San Antonio, Special Report 11.

Texas Historical Commission

1981 Guidelines for Archeological Investigations of Mining Areas in Texas. Office of the State Archeologist, Texas Historical Commission. Austin.

Thompson, W. A.

1975 History of the Dairy Industry in the Tri-County Area of Falfurrias, Texas. Unpublished M.A. thesis, Southwestern Graduate School of Banking, Texas A\&I University, Kingsville.

Webb, W. P. and H. B. Carroll

1952 The Handbook of Texas. The Texas State Historical Association, Austin. 
